OPEN ACCESS

Edited by:

Prashant Trikha,

Nationwide Children's Hospital,

United States

Reviewed by:

Xiaofeng Yang,

Temple University, United States

Dennis O. Adeegbe,

Moffitt Cancer Center, United States

*Correspondence:

Pamela S. Ohashi

pohashi@uhnresearch.ca

Specialty section:

This article was submitted to

Cancer Immunity and Immunotherapy,

a section of the journa

Frontiers in Oncology

Received: 24 January 2019 Accepted: 26 March 2019

Published: 16 April 2019

Citation:

Han S, Toker A, Liu ZQ and Ohashi PS (2019) Turning the Tide Against

Regulatory T Cells.

Front. Oncol. 9:279.

doi: 10.3389/fonc.2019.00279

\section{Turning the Tide Against Regulatory T Cells}

\author{
SeongJun Han ${ }^{1,2}$, Aras Toker ${ }^{1}$, Zhe Qi Liu ${ }^{1,2}$ and Pamela S. Ohashi ${ }^{1,2,3 *}$ \\ ${ }_{1}^{1}$ Princess Margaret Cancer Centre, Campbell Family Institute for Breast Cancer Research, University Health Network, \\ Toronto, ON, Canada, ${ }^{2}$ Department of Immunology, Faculty of Medicine, University of Toronto, Toronto, ON, Canada, \\ ${ }^{3}$ Department of Medical Biophysics, Faculty of Medicine, University of Toronto, Toronto, ON, Canada
}

Regulatory $T$ (Treg) cells play crucial roles in health and disease through their immunosuppressive properties against various immune cells. In this review we will focus on the inhibitory role of Treg cells in anti-tumor immunity. We outline how Treg cells restrict $T$ cell function based on our understanding of $T$ cell biology, and how we can shift the equilibrium against regulatory $T$ cells. To date, numerous strategies have been proposed to limit the suppressive effects of Treg cells, including Treg cell neutralization, destabilizing Treg cells and rendering $T$ cells resistant to Treg cells. Here, we focus on key mechanisms which render T cells resistant to the suppressive effects of Treg cells. Lastly, we also examine current limitations and caveats of overcoming the inhibitory activity of Treg cells, and briefly discuss the potential to target Treg cell resistance in the context of anti-tumor immunity.

Keywords: immune regulation, Treg cells, $\mathrm{T}$ cells, tumor immunity, immune therapy

\section{INTRODUCTION-REGULATORY T CELL IN CANCER Challenges in Immune-Oncology-Immunosuppressive Cells}

The concept of utilizing the $\mathrm{T}$ cells, to recognize and eliminate cancer cells has contributed to the advancement of immunotherapy against multiple malignancies. Recent advances in checkpoint inhibitors (in particular CTLA-4 and PD-1 inhibitors) and cell-based therapy such as Chimeric Antigen Receptor (CAR) - T cell therapy demonstrate promising clinical responses in various cancer types in a subset of patients. However, despite the attempts to modulate anti-tumor T cell responses, a proportion of patients still do not respond to these immune therapies (1-3). The mechanisms of resistance against immune therapy is currently a key area of investigation. Some of these mechanisms include the presence of immunoregulatory cells in the tumor microenvironment such as tumor-associated macrophages (TAMs), myeloid-derived suppressor cells (MDSCs) and regulatory $\mathrm{T}$ (Treg) cells which could play an important role in restricting $\mathrm{T}$ cell immunity (4-6). Thus, overcoming the effects of these immunosuppressive cells remain a challenge for those seeking to enhance anti-tumor immune response.

\section{Evidence for a Role for Regulatory T Cells in Anti-tumor Immunity}

Treg cells are one of the integral components of the adaptive immune system that contribute to maintaining tolerance to self-antigens and preventing autoimmune diseases $(7,8)$. It is postulated that these cells have an important role in regulating immune surveillance and promoting tumor progression. However, their precise role in regulating anti-tumor immunity and the mechanism of how Treg cells could suppress T cells in tumor is still unclear (9). Early studies used CD4 ${ }^{+} \mathrm{CD} 25^{+}$ markers to identify Treg cells with the caveat that activated helper $\mathrm{T}$ cells would also express these markers (10). Woo et al. (11) provided evidence for the presence of regulatory $\mathrm{T}$ in patients with 
early-stage non-small cell lung cancer and late-stage ovarian cancer. Numerous other manuscripts have also noted the presence of potential $\mathrm{CD} 4{ }^{+} \mathrm{CD} 25^{+}$Treg cells in multiple types of cancer including melanoma, pancreatic cancer and breast cancer (12-14).

In 2003, studies reported that the transcription factor FoxP3 was critical for Treg development (15-17), Subsequently, Curiel et al. (18) examined $\mathrm{CD} 4{ }^{+} \mathrm{CD} 25^{+} \mathrm{FoxP}^{+}$cells and found that increased infiltration of Treg cells correlated with disease progression in ovarian carcinoma, and infiltration of these cells in each stage of cancer served as a good metric for survival prediction. Similarly, studies demonstrated that the presence of Treg cells in breast cancer correlated with reduced overall survival $(19,20)$. In contrast, several reports suggested that infiltration of Treg cells can be a favorable prognostic factor (21-24). Such discrepancies may result from the inability to precisely identify regulatory $\mathrm{T}$ cells within the heterogenous pool of FoxP3 ${ }^{+}$expressing $\mathrm{CD}^{+}{ }^{+} \mathrm{T}$ cells (25). Alternatively, considering high infiltration of Treg cells also correlate with high infiltration of CD8 ${ }^{+} \mathrm{T}$ cells in a specific tumor subtypes (24), regulatory $\mathrm{T}$ cells may be recruited in response to an inflamed tumor microenvironment. Part of the controversy could also be due to the finding that FoxP3 can be transiently upregulated in activated human T cells, and is therefore not an exclusive marker for Treg cells $(25,26)$. The expression level of other markers such as CD45RA (27) and Treg-specific DNA demethylation status within the FoxP3 locus can increase the accuracy of identifying functionally active Treg cells $(28,29)$. However, it is not always possible to perform these in depth analysis. Studies have also utilized ex vivo Treg suppression assays to demonstrate the presence of regulatory $\mathrm{T}$ cells within tumor tissue $(18,30,31)$.

In mice, the role of Treg cells in regulating anti-tumor immunity has been investigated through ablation of Treg cells (using FoxP3 ${ }^{\mathrm{DTR}}$ mice or antibodies targeting receptors highly expressed on Treg cells, such as CD25, GITR, and folate receptor 4) in transplantable tumor models (32-35). In these models, depletion of regulatory $\mathrm{T}$ cells in conjunction with modulation of $\mathrm{T}$ cell immunity improves anti-tumor immunity. In contrast, co-adoptive transfer of $\mathrm{CD} 8^{+} \mathrm{T}$ cells with Treg cells prevented effective adoptive cell therapy against B16-F10 melanoma (36). In summary, although the presence of Treg cells in tumors cannot be used as an accurate prognostic factor, the literature suggests that Treg cells are a potent regulator of anti-tumor immunity.

\section{Immune Therapy and Treg Cells}

One potential mechanism that may reduce the efficacy of cancer immunotherapy is suppression mediated by the Treg cell population. In addition, the therapeutic modalities such as anti-PD-1 may potentially alter Treg cell function and/or frequency, either directly or indirectly by changing the immune microenvironment (37-39). Thus, the potential effect of Treg cells on tumor-specific $\mathrm{T}$ cells should not be neglected even in therapeutic arena.

One of the most predominantly utilized checkpoint inhibitors in clinical and translational studies involve therapeutic blockade of PD-1 (nivolumab and pembrolizumab) or PDL-1 (atezolizumab and duravalumab) (40). There is a limited number of clinical studies thoroughly documenting changes in the quantity and quality of Treg cells in response to these PD-1/PDL1 inhibitors. To date, studies either report an increase or no change in the frequency of Treg cells in response to nivolumab or pembrolizumab $(39,41)$. It is also important to note that PD-1 and PD-L1 can be expressed by Treg cells, thus direct modulation of Treg cell function should not be excluded as a possibility $(31,42-44)$. A few reports demonstrate that PD-1 blockade attenuates Treg cell suppression in vitro, based on the effect of PD-1 inhibitor on $\mathrm{T}$ cell proliferation in the presence of Treg cells $(39,45,46)$. However, the effect of these inhibitors on Treg cells have not been clearly discriminated against its effect on $\mathrm{T}$ cells. A few reports including a study conducted by Toor et al. $(47,48)$ suggest that PD-1 blockade does not modulate Treg cell phenotype or function, but instead targets activated T cells. A murine study conducted by Chen et al. (49) demonstrates that PD-1 has no influence over the development and suppressive effects of thymically-derived Treg cells, however PD-1 appears to be crucial for differentiation of naïve $\mathrm{CD} 4^{+}$ $\mathrm{T}$ cells into iTregs. Similarly, PD-L1 blockade can interfere with the induction and maintenance of iTreg cells in mice (50). Collectively, the precise effect of PD-1 blockade on Treg cells is poorly understood. Nevertheless, PD-1 inhibition synergizes with therapeutic strategies which reduce the quantity of Treg cells in mice $(35,51,52)$, suggesting that enhanced anti-tumor immunity in response to PD-1 blockade may still be limited by Treg cells. Extensive studies have been performed evaluating the clinical potential of interfering with immune checkpoint receptors beyond PD-1, including CTLA-4, LAG-3, and TIM-3. However, the effect of each checkpoint inhibitors on Treg cells is also poorly understood and are beyond the scope of this review.

Adoptive cell therapies using TCR transduced T cells, CART cells and Tumor-infiltrating Lymphocytes (TIL) are capable of directly recognizing and targeting tumor cells $(3,53)$. However, whether or not these $\mathrm{T}$ cell products are susceptible to regulation by Treg cells in humans is yet to be elucidated. In a few cases, the frequency of lymphocytes resembling Treg cells increases with adoptive $\mathrm{T}$ cell therapy $(37,38,54)$. In the context of TIL therapy, Yao et al. (37) has demonstrated that the quantity of Treg cells reconstituted after non-myeloablative chemotherapy, which correlates with the number of administered doses of IL-2, is associated with patient responsiveness to TIL therapy. Supportive of this finding, administration of high-dose IL-2 (often utilized in conjunction with TIL therapy) can result in expansion of immunosuppressive ICOS $^{+}$Treg cells, which may be predictive of clinical outcomes in patients with metastatic melanoma (55). Baba et al. (56) utilized a murine model of fibrosarcoma to suggest that rapid reconstitution of Treg cells post-lymphodepletion suppress anti-tumor immunity, and targeting these regulatory $\mathrm{T}$ cells using neutralizing antibodies significantly reduced tumor growth. In the context of CAR$\mathrm{T}$ cell therapy, the effect of the treatment on Treg cells may vary. For instance, clinical infusion of EGFRvIII-directed CAR$\mathrm{T}$ cells for the treatment of glioblastoma resulted in influx of $\mathrm{CD}^{+}{ }^{+} \mathrm{CD} 25^{+}$FoxP $^{+}$cells in the tumor (38), whereas CD19targeted CAR-T cells against B-cell lymphoma and leukemia did not increase the frequency of Treg cells (57). Lymphodepletion, 
known to transiently reduce the frequency of Treg cells, improves persistence of CAR-T cells as well as therapeutic outcome (58), however the direct effect of Treg cells on CAR-T cells is unknown. In summary, the role of regulatory $\mathrm{T}$ cells in the context of adoptive $\mathrm{T}$ cell therapy is currently unknown, however the literature suggests that Treg cells may limit the outcome of these therapeutic modalities.

\section{Mechanisms of Treg Suppression}

The general mechanisms of $\mathrm{T}$ cell suppression by Treg cells, mostly evaluated through in vitro experiments, suggest that Treg cells may exploit diverse contact-dependent and cytokinemediated mechanisms to limit $\mathrm{T}$ cell function $(59,60)$. One of the proposed mechanisms involve the ability of Treg cells to downregulate CD80/86 expression on dendritic cells (61-63). In a study conducted by Wing et al. $(62,64)$ and Onishi et al. (63), Treg-specific deletion of CTLA-4, which binds to CD80/86, results in reduced suppressive effects of Treg cells in vivo and failed to downregulate CD80/CD86 expression on dendritic cells (DCs) in vitro. Qureshi et al. (65) also demonstrate that CTLA4 can reduce CD80/CD86 expression on DCs through transendocytosis and subsequent degradation of the co-stimulatory molecules. Furthermore, in vitro engagement of CTLA-4 with cognate receptors on DCs reduces the secretion of cytokines by DCs such as IL-6 and TNF, while increasing the expression of IDO, an immunosuppressive tryptophan catabolizing enzyme $(66,67)$. However, evidence also suggests that Treg cells can maintain suppressive functions without CTLA-4. For example, Paterson et al. (68) demonstrated that conditional ablation of CTLA-4 in adult mice do not result in systemic autoimmunity as observed in germline CTLA-4 deficiency, and also suggested that these Treg cells deficient in CTLA- 4 are functional both in vitro and in vivo. Several other potential mechanisms of $\mathrm{T}$ cell suppression have been proposed, including (1) increased interaction between Treg cells and dendritic cells through high expression of LFA-1 on Treg cells resulting in reduced $\mathrm{T}$ cell priming $(63,69)$, (2) perforin and granzyme-mediated lysis of effector T cells (70-72), and (3) CD39 and CD73mediated metabolic disruption of T cells (73). Through in vitro experiments, Deaglio et al. (73) suggested that CD39 and CD73 (ectonucleotidases used for hydrolysis of phosphate residues) expression by Treg cells can induce hydrolysis of extracellular ATP to adenosine, which triggers $\mathrm{A} 2 \mathrm{~A}$ receptor on $\mathrm{T}$ cells and elevates intra-cellular cAMP for T cell inhibition. However, most of these proposed mechanisms have not been explored in vivo.

Treg cells may also attenuate the $\mathrm{T}$ cell response via the production of chemokines and inhibitory cytokines. Treg cells can secrete TGF- $\beta$, IL-10, and IL-35 in a context-dependent manner, and reduce effector $\mathrm{T}$ cell function (74-77). For example, TGF- $\beta$ can be a potent regulator of CTL function in vitro and in vivo $(76,78,79)$, and reduce anti-tumor immunity in a transplantable tumor model $(76,79,80)$. Although the secretion of TGF- $\beta$ by Treg cells appears to be an important mechanism of suppression, an in vitro study conducted by Piccirillo et al. (81) also suggests that blockade of TGF- $\beta$ produced by regulatory $\mathrm{T}$ cells do not reduce the suppressive effects of Treg cells. The role of IL-10 on T cells is unclear due to evidence of IL-10 serving as either stimulatory or inhibitory cytokine in a context-dependent manner, however evidence suggests that IL-10 plays an important role in Treg cell-mediated suppression of $\mathrm{T}$ cells $(82,83)$. For instance, Chaudhry et al. (82) suggests that IL-10 signaling acts on Treg cells to attenuate pathogenic $\mathrm{T}_{\mathrm{h}} 17$ response, however, the molecular mechanism of $\mathrm{T}$ cell suppression is still unclear. Similarly, the precise mechanism of T cell inhibition by IL-35 is also unclear, but studies suggest that IL-35 restricts T cell proliferation and induces "infectious tolerance" by inducing Treg cells from naïve CD4 ${ }^{+}$T cells $(84,85)$. Lastly, in conjunction with previously described cytokine-driven suppressive mechanisms, it has been recently demonstrated in EAE and islet allograft models that secretion of the chemokines CCL3 and CCL4 by Treg cells plays an important role in the recruitment of effector $\mathrm{T}$ cells to close proximity of Treg cells where they become susceptible to suppression (86).

Lastly, in vitro Treg suppression assays suggest that Treg cells compete with other T cells for IL-2, and that the decreased availability of IL-2 reduces T cell proliferation and function (8789). In this particular system, Treg cells constitutively express a high level of high-affinity IL-2 receptors whereas stimulated naïve $\mathrm{T}$ cells do not express high-affinity IL-2 receptors at an earlier time point; this may further contribute to preferential acquisition of IL- 2 by Treg cells. Furthermore, IL- 2 provides STAT5 signaling in Treg cells that is necessary to further enhance their immunosuppressive function $(90,91)$. This particular mechanism of suppression can also be observed in vivo. A study conducted by Chinen et al. (91) suggest that the ability of Treg cells to capture and compete for IL-2 is critical for controlling $\mathrm{CD}^{+} \mathrm{T}$ cell expansion and function. The general consensus for those investigating Treg cell-mediated suppression of $\mathrm{T}$ cells is that each suppressive mechanism likely acts in a contextdependent manner and more than one mechanism could be employed simultaneously to inhibit $\mathrm{T}$ cell function $(7,59)$. Thus, the ability of Treg cells to compete for IL-2 likely works in tandem with other suppressive mechanisms to regulate $\mathrm{T}$ cell immunity.

It remains unclear which of the previously described mechanisms are relevant for regulatory $\mathrm{T}$ cells residing in the tumor. Treg cells found in the tumor often display a distinct phenotype in comparison to those circulating the periphery, which is exemplified through their unique transcriptional signatures and the expression of markers including PD-1 (31, $43,44,92,93)$. In the context of head and neck squamous cell carcinoma, tumor-infiltrating $\mathrm{CD}^{+}{ }^{+} \mathrm{CD} 25^{\text {hi }}$ Foxp $3^{+} \mathrm{T}$ cells produce a higher level of TGF- $\beta$ and reduced T cell proliferation more effectively than Treg cells from the periphery in Treg suppression assays $(30,94)$. These correlative studies suggest that intra-tumoral Treg cells display highly immunosuppressive phenotype in vitro, suggesting that they may regulate antitumor immunity. However, it is still unclear precisely "when," "where" and "how" these distinct Treg cells exert their suppressive effect in cancer biology. Most in vivo and in vitro experiments performed to elucidate the cellular and molecular mechanism of $\mathrm{T}$ cell suppression by Treg cells in mice were performed using Treg cells from secondary lymphoid organs such as spleen and lymph nodes, and therefore may not fully recapitulate the interaction between intra-tumoral Treg 
cells and T cells. Nevertheless, evidence acquired from studies using non-tumor derived Treg cells may provide insights in understanding how intra-tumoral Treg cells could potentially limit anti-tumor $\mathrm{T}$ cells.

\section{Potential Strategies to Interfere With Immune Suppression by Regulatory T Cells}

Acknowledging the significance of Treg cells and their potential role in inhibiting anti-tumor immunity, multiple strategies have been proposed to deplete Treg cells in vivo. However, one major challenge associated with Treg cell depletion is the lack of a Treg cell-specific marker. Most surface molecules expressed on Treg cells are also present on activated $\mathrm{T}$ cells, although the level of expression may be different. Similarly, FoxP3 is expressed by both activated $\mathrm{T}$ cells and Treg cells in humans $(25,26)$. Despite such challenges, several potential strategies have been proposed to reduce the suppressive effects of Treg cells (Figure 1). First, several non-specific anti-cancer drugs have been shown to reduce Treg cell activities. Low-dose cyclophosphamide (CTX), a common chemotherapeutic agent known to target rapidly dividing cells, significantly reduced Treg cells owing to their higher rate of proliferation, leading to enhanced anti-tumor immunity (95-98). In these studies, investigators have noted that CTX reduced the levels of intra-tumoral Treg cells while maintaining or elevating the level of $\mathrm{CD}^{+} \mathrm{T}$ cells in the tumor $(96,97)$. In contrast, several studies have reported contradicting data where CTX either increased the level of Treg cells or did not enhance anti-tumor immunity $(99,100)$. Additional studies showed that treatment with CTX was further improved in its selectivity and efficacy through combination therapy with OX40 agonist or anti-PD-1, demonstrating increased intra-tumoral Teff/Treg cell ratio and subsequent regression of B16 and TC1 tumors $(101,102)$. Several other FDA-approved anti-cancer agents including tyrosine kinase inhibitors sunitinib, sorafenib, and imatinib also reduced the levels of intra-tumoral Treg cells $(101,103-105)$.

While specific targeting of tumor-infiltrating Treg cells can be challenging, several agents including daclizumab (CD25 blocking antibody), denileukin diftitox (Ontak, IL-2-diphtheria toxin conjugate protein), and several other antibodies have been proposed to target Treg cells and enhance anti-tumor immunity $(106,107)$ (Figure 1). First, the use of CD25 to target and deplete Treg cells has resulted in improved anti-tumor immunity in some cases $(108,109)$. However, this strategy has raised a number of concerns based on inconsistent in vivo responses and lack of specificity. Similar to the effects of antiCD25 in mice (clone PC-61), the use of denileukin diftitox for depleting Treg cells and eliciting a stronger anti-tumor immune response remains controversial, due to varying clinical responses $(110,111)$. For instance, treatment of patients with renal cell carcinoma using denileukin diftitox effectively relieved inhibition by Treg cells to promote anti-tumor immunity, but the opposite trend was observed in patients with metastatic melanoma $(110,111)$. Tumor heterogeneity, the existence of CD25 ${ }^{-}$Treg cells and CD25 expression on other immune cells, such as T cells, B cells, and NK cells $(112,113)$, may explain seemingly opposite outcomes in this particular approach. However, recent studies have further modified and improved strategies targeting CD25 and suggest that it may still be a viable option to restrict Treg cell activities. Arce Vargas et al. (35) demonstrated that Fc-optimized antibodies against CD25 could effectively reduce the frequency of intra-tumoral Treg cells and improve tumor control. Furthermore, CD25targeted near-infrared photoimmunotherapy (NIR-PIT) has been developed in a murine model. By conjugating anti-CD25 with a photoactivatable silica-phthalocyanine dye sensitive to nearinfrared light, and localizing near-infrared irradiation specifically on tumors, NIR-PIT achieved reduction of intra-tumoral Treg cells (114).

Beyond CD25 as a target molecule, regulatory $\mathrm{T}$ cells constitutively express receptors such as GITR, CTLA-4, and folate receptor 4 . In the tumor microenvironment, Treg cells further upregulate a large number of receptors including ICOS, OX40, GITR, TIGIT, PD-1, and CTLA-4 (31, 115). Antibodies targeting some of these receptors expressed by Treg cells such as GITR and folate receptor 4 reduce the amount of Treg cells and enhance anti-tumor immunity in mice $(32,33,116)$. Similarly, checkpoint inhibitors designed to block inhibitory signals on $\mathrm{T}$ cells may also play an important role in regulating Treg cell activities. With Treg cells expressing a high level of CTLA-4 (27), administration of an anti-CTLA-4 antibody has resulted in a major reduction in the frequency of intratumoral CTLA $-4^{+}$FoxP3 ${ }^{+}$Treg cells which was dependent on $\mathrm{Fc} \gamma$ receptor-expressing cells in the tumor microenvironment (117-121). This is consistent with the correlation of decreased frequency of tumor-infiltrating Treg cells with the usage of ipilimumab in patients with bladder cancer and advanced melanoma (122-124). Lastly, a study conducted by Sugiyama et al. (125) demonstrated that a high proportion of Treg cells express CCR4 in tumor-infiltrating lymphocytes (TILs) acquired from melanoma patients. CCR4 expression was specific to CD ${ }^{+}$CD $45 \mathrm{RA}^{-}$FoxP $3{ }^{\text {hi }}$ Treg cells, a terminally differentiated and highly suppressive subset of Treg cells that preferentially accumulates within tumors, whereas CCR4 is not expressed on $\mathrm{CD}^{+}{ }^{+} \mathrm{CD} 45 \mathrm{RA}^{+}$FoxP3 $^{\text {lo }}$ naïve $\mathrm{T}$ cells. In agreement with these findings, administration of anti-CCR4 (Mogamulizumab) in patients with Adult T-Cell Leukemia-Lymphoma (expressing NY-ESO-1) resulted in reduction in $\mathrm{CD}^{+}{ }^{+} \mathrm{CD} 45 \mathrm{RA}^{-}$FoxP 3 hi Treg cells and enhanced NY-ESO-1-specific $\mathrm{CD}^{+} \mathrm{T}$ cell response (125). Although anti-CCR4 antibodies target a specific subset of Treg cells that are highly abundant within tumors, this particular strategy does not selectively deplete intra-tumoral Treg cells since a large proportion of Treg cells in peripheral blood are $\mathrm{CD}^{+}{ }^{+} \mathrm{CD} 45 \mathrm{RA}^{-}{ }^{-} \mathrm{CCR} 4{ }^{+}$FoxP3 ${ }^{+}$Treg cells $(8,27,125)$.

Interestingly, studies published within the last few years suggest that promoting the conversion of Treg cells into immune-stimulatory cells could be an alternative approach to enhancing anti-tumor immunity (Figure 1). FoxP3 ${ }^{+}$regulatory $\mathrm{T}$ cells are comprised of heterogenous sub-populations of cells some of which display functional plasticity. Depending on the environmental cues, these Treg cells remain uncommitted and become susceptible to being re-programmed to FoxP3helper $\mathrm{T}$ cells or $\mathrm{FoxP}^{+}$cells which display properties of 


\begin{tabular}{|c|c|}
\hline Strategies & Examples \\
\hline $\begin{array}{l}\text { Non-Specific Anti-Cancer Drugs } \\
\text { Certain chemotherapeutic agents } \\
\text { were found to reduce the frequency of } \\
\text { Treg cells and enhance anti-tumor } \\
\text { immunity. }\end{array}$ & $\begin{array}{l}\text { Cyclophosphamide } \\
\text { Tyrosine kinase inhibitors } \\
\text { sunitimab } \\
\text { sorafenib } \\
\text { imatinib }\end{array}$ \\
\hline $\begin{array}{l}\text { Treg Cell-Depleting Agents } \\
\text { Treg cells express numerous receptors } \\
\text { which can be targeted to reduce the cell } \\
\text { frequency and subsequently enhance } \\
\text { anti-tumor immunity. }\end{array}$ & $\begin{array}{l}\text { Daclizumab (anti-CD25 antibody) } \\
\text { Denileukin difitox (IL-2-diptheria toxin conjugate) } \\
\text { Fc-optimized anti-CD25 antibody } \\
\text { CD25-targeted NIR-PIT } \\
\text { MK-4166, DTA-1 (anti-GITR antibody) } \\
\text { Anti-folate receptor } 4 \text { antibody } \\
\text { Ipilimumab (anti-CTLA4 antibody) } \\
\text { Mogamulizumab (anti-CCR4 antibody) }\end{array}$ \\
\hline $\begin{array}{ll}\text { Treg cell } & \begin{array}{l}\text { Conversion of Treg Cells to } \\
\text { Immune-Stimulating Cells }\end{array} \\
\begin{array}{c}\text { Effector-Like } \\
\text { Cell }\end{array} & \begin{array}{l}\text { Disrupting the stability of intra-tumoral } \\
\text { IFNY }\end{array} \\
\begin{array}{l}\text { Treg cells using antibody or epigenetic } \\
\text { modifiers have found to be an alternative } \\
\text { approach to enhance anti-tumor } \\
\text { immunity. }\end{array}\end{array}$ & $\begin{array}{l}\text { Anti-neuropilin-1 antibody } \\
\text { EZH2 inhibitor } \\
\text { BET bromodomain inhibitor (JQ1) } \\
\text { Ep300 inhibitor }\end{array}$ \\
\hline
\end{tabular}

FIGURE 1 | Regulatory T cells can be targeted through chemotherapeutic agents, neutralizing antibodies and epigenetic modifiers. Chemotherapeutic agents reduce the quantity of Treg cells and synergize with immune-modulatory drugs to enhance anti-tumor immunity. However, these approaches are not necessarily specific to Treg cells. Surface markers expressed on Treg cells (such as CD25, GITR, folate receptor 4, CTLA-4, and CCR4) can be targeted to more reliably reduce the quantity of Treg cells. Recent approaches involve conversion of Treg cells into "effector-like" CD4 ${ }^{+}$T cells through the use of neutralizing antibodies as well as epigenetic modifiers.

a helper T cell (126-129). Similarly, there are heterogenous populations of highly suppressive Treg cells in the tumor microenvironment. Although the composition and function of these tumor-infiltrating Treg cells is still a topic of debate, evidence suggest that both thymically-derived natural Treg cells, characterized by high expression of neuropilin-1, and induced Treg cells play important role in regulating antitumor immunity (130). Peripherally-derived regulatory T cells, which display greater plasticity, can be targeted to enhance anti-tumor immunity (130, 131). Furthermore, despite the initial assumption that thymically derived Treg cells undergo a strict lineage commitment, Overacre-Delgoffe et al. (132) demonstrated that targeting neuropilin-1 on Treg cells induces IFN $\gamma$ production and "functional fragility" which can in turn enhance anti-tumor immunity. A recent approach of converting Treg cells into immune-stimulatory cells in the context of tumor immunity involve epigenetic modification of intratumoral Treg cells to disrupt their lineage and functional stability. For example, Wang et al. (133) have demonstrated that the histone H3K27 methyltransferase enhancer of zeste homolog 2 (EZH2) activities are increased in tumor-infiltrating Treg cells in both murine and human cancers, and molecular targeting of EZH2 promoted conversion of Treg cells into IFN $\gamma$ producing cells that were capable of remodeling the tumor microenvironment and enhancing anti-tumor immunity. Several other epigenetic modifiers such as Bromodomain and ExtraTerminal (BET) family proteins and histone acetyltransferase Ep300 can also be targeted to disrupt Treg cell function and improve anti-tumor immune response (134, 135). However, these epigenetic modifiers possess other biological functions, and molecular targeting of these proteins could potentially induce off-target effects.

Despite these alternative approaches to Treg cell blocking or depletion strategies, limitations still exist, including the lack of a Treg cell-specific biomarker and potential induction of autoimmunity as a consequence of systemic Treg cell depletion (136, 137). Lastly, depletion of Treg cells can be followed by their rapid reconstitution, often resulting in a higher frequency in comparison to the level of Treg cells prior to depletion $(138,139)$. Alternatively, another approach to enhance antitumor immunity would be to modify tumor-specific $\mathrm{T}$ cells to be resistant to the suppressive effects of Treg cells. This approach may be relevant when adoptive $\mathrm{T}$ cell therapies are used including TCR transduction with tumor specific TCR or CAR-T cells.

\section{REPORTED CASES OF TREG RESISTANCE}

Since the early 2000s, evidence suggests that there are a variety of molecular pathways and cellular mechanisms which render $\mathrm{T}$ cells resistant to the suppressive effects of Treg cells. Numerous surface receptors, intracellular signaling molecules and cytokines have been implicated in T cell resistance to Treg cells (Figure 2).

\section{Intracellular and Receptor Targets Controlling Treg Resistance \\ E3 Ubiquitin Ligase Cbl-b}

The inhibition of E3 ubiquitin ligase Cbl-b has shown promising results based on the ability of $\mathrm{T}$ cells to resist the suppressive effects of Treg cells both in vitro and in vivo $(140,141)$. Through 


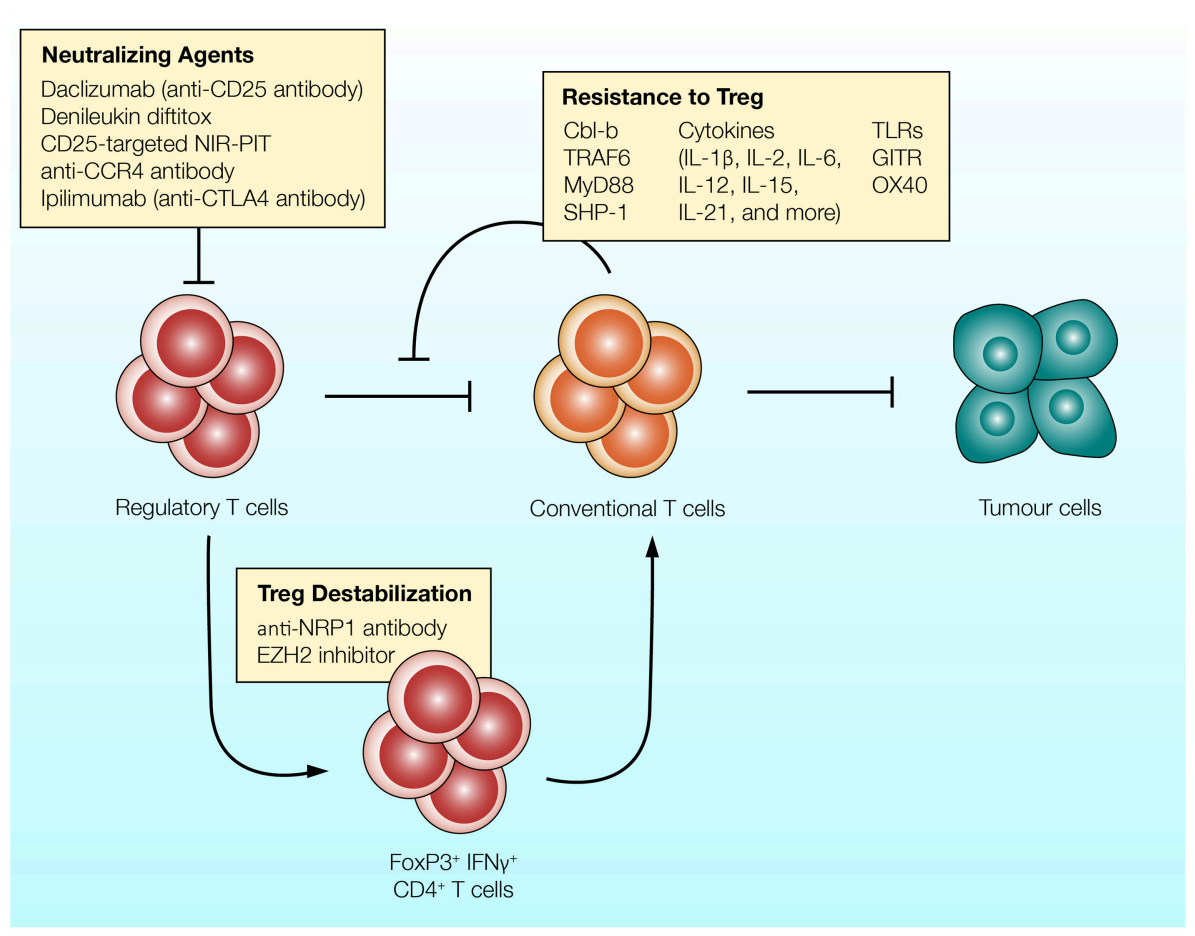

FIGURE 2 | Different strategies can be utilized to overcome the suppressive effects of Treg cells. (1) Antibodies targeting CD25, CCR4, or CTLA-4 expressed on Treg cells can be used to reduce the frequency of regulatory T cells and enhance anti-tumor immunity. (2) Regulatory T cells can convert into $T$ cell stimulatory cells in response to inhibition of EZH2 epigenetic modifier or NRP-1-targeting antibody. Treg cells treated with these agents upregulate IFN $\gamma$ and enhance anti-tumor immunity $(132,133)$. (3) T cells can be rendered resistant to the suppressive effects of Treg cells. Intracellular molecules which govern T cell activation (such as Cbl-b and TRAF-6), co-stimulatory receptors (such as TLRs and GITR) and various T cell stimulatory cytokines reduce the ability of Treg cells to suppress T cells.

ubiquitination (and in many cases, subsequent ubiquitinmediated degradation) or phosphorylation of proteins involved in the TCR signaling pathway, Cbl-b serves as a negative regulator of antigen-induced $\mathrm{T}$ cell activation (142). Several molecular targets have been identified, including PKC $\theta$, Nedd4, PLC- $\gamma 1$, Vav1, LAT, and p85, along with several other TCR signaling molecules that play an important role in $\mathrm{T}$ cell activation (143-147). Consequently, through the regulation of these molecules, Cbl-b can control a diverse repertoire of intracellular mechanisms associated with the early phase of T cell activation, such as calcium influx, cytoskeletal rearrangement, immune synapse formation, cytokine secretion as well as proliferation (148, 149). Amongst several signaling pathways downstream of TCR activation, reports highlight the role of PI3K/Akt signaling pathway in $\mathrm{T}$ cell resistance to Treg cellmediated suppression $(150,151)$. Interestingly, it has become evident that that PI3K and Cbl-b are indirectly regulated by each other to control $\mathrm{T}$ proliferation (Figure 3). Fang et al. (143) has suggested that Cbl-b regulates the PI3K signaling pathway by binding and ubiquitinating a PI3K regulatory subunit p85. However, a study conducted by Guo et al. (146) offers an alternative explanation where Cbl-b does not directly inhibit PI3K, but instead inhibits the Nedd4-mediated ubiquitination of PTEN, a negative regulator of PI3K activity. Adding to the complexity of the interaction between PI3K/Akt pathway and
Cbl-b, Akt also negatively regulates Cbl-b protein level through inactivation of GSK-3, a protein kinase which enhances Cblb activity by catalyzing the phosphorylation at Ser476 and Ser480 (152).

In addition to the ability of Cbl-b to regulate molecular pathways associated with TCR signaling, evidence suggests Cbl-b is intertwined with multiple $\mathrm{T}$ cell inhibitory signaling pathways. Early studies demonstrated that Cbl-b can be re-expressed in response to CTLA-4 signaling, and CTLA-4 deficient T cells display reduced Cbl-b expression (153). Recent studies suggest that $\mathrm{T}$ cells deficient in Cbl-b are less susceptible to PD1 inhibitory signaling in vitro $(154,155)$. These findings are consistent with a study suggesting that SHP-1, which plays an important role in downstream PD-1 and CTLA-4 signaling pathway, controls Cbl-b activity through direct phosphorylation (156). Furthermore, a study conducted by Mercadante and Lorenz (157) utilizes an in vitro Treg suppression assay and homeostatic in vivo Treg suppression assay to demonstrate that SHP-1 deficient $\mathrm{T}$ cells are less responsive to the suppressive effects of Treg cells. These studies suggest that Cbl-b is linked with key negative regulatory pathways in T cells. Lastly, Cbl$\mathrm{b}$ is also intertwined with TGF- $\beta$ receptor signaling. Gruber et al. (158) demonstrated that Cbl-b directly ubiquitinates and subsequently downregulates SMAD7, an attenuator of TGF- $\beta$ receptor signaling. Consistent with this finding, $\mathrm{CD} 4^{+} \mathrm{T}$ cells 


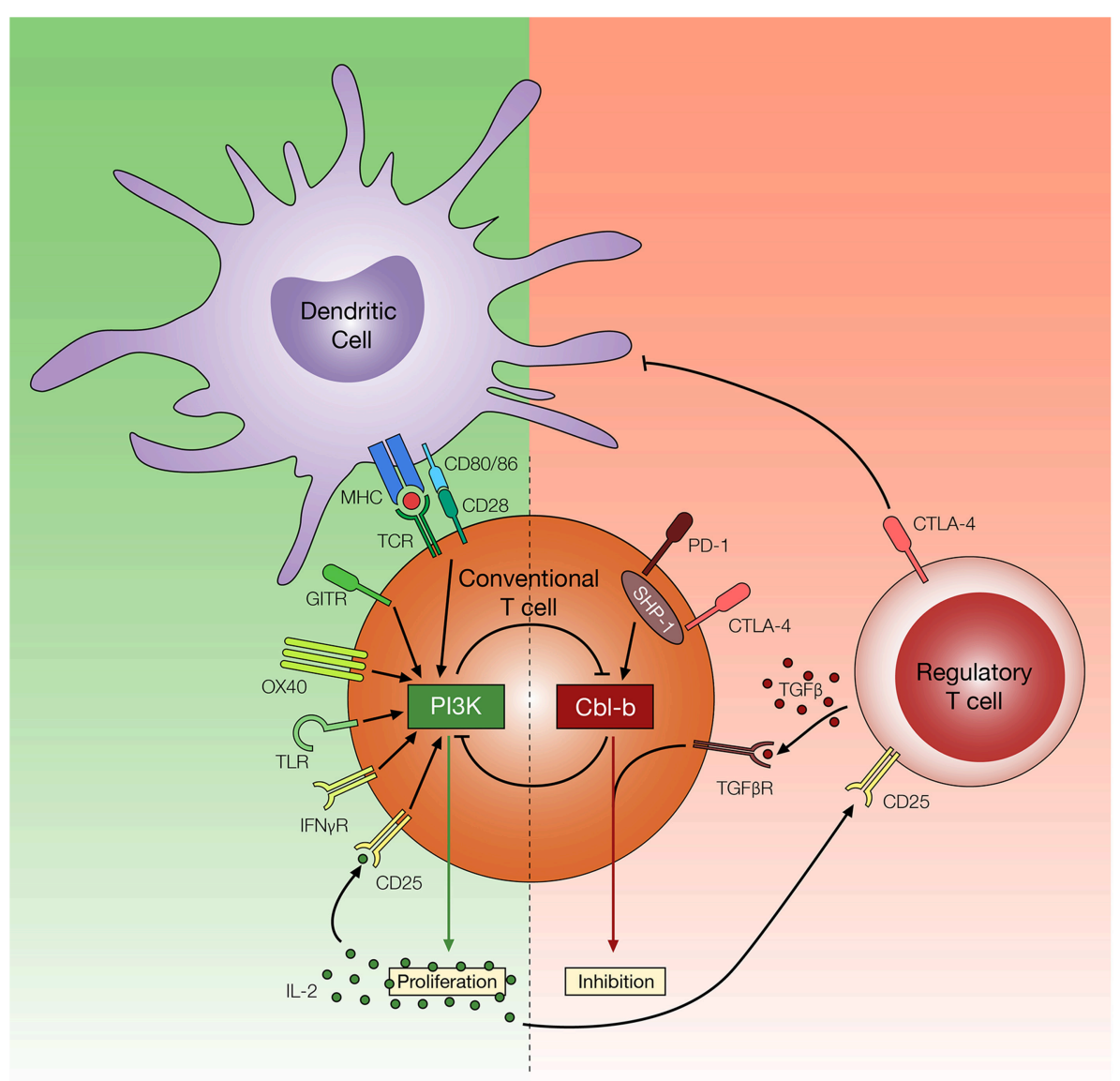

FIGURE 3 | Potential mechanisms of T cell resistance to Treg cells. Regulatory T cells utilize multiple inhibitory mechanisms to limit T cell activation and proliferation, such as downregulation of CD80/86 on DCs, secretion of TGF- $\beta$, and consumption of IL-2. Reports suggest amplified PI3K signaling, through TCR, co-stimulatory and cytokine receptors, may render T cells resistant to these effects of Treg cells. In contrast, Cbl-b plays an important role in regulating diverse arms of the TCR signaling pathways and promoting $T$ cell inhibition. Cbl-b deficient T cells are refractory to Treg cell-mediated suppression, but the mechanism of Treg cell resistance remains yet to be elucidated.

deficient in Cbl-b display reduced sensitivity to TGF- $\beta$ mediated inhibition $(140,141,158,159)$. The multi-faceted role of Cbl$\mathrm{b}$ in regulating TCR signaling pathways as well the inhibitory signaling pathway enables Cbl-b deficient T cells to acquire TCR sensitivity, CD28-independent stimulation, increased cytokine production, and context-dependent TGF- $\beta$ insensitivity (141, 160 ), all of which potentially contribute to $\mathrm{T}$ cell resistance to Treg cell-mediated suppression (Figure 3).

Cbl-b deficient $\mathrm{CD}^{+}$and $\mathrm{CD}^{+}{ }^{+} \mathrm{T}$ cells resist Treg cellmediated suppression in an in vitro Treg suppression assay,

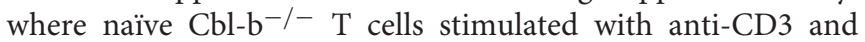
irradiated APCs are capable of overcoming the suppressive effects of splenic Treg cells $(140,161)$. However, (1) the ability of Cbl$\mathrm{b}^{-/-} \mathrm{T}$ cells to resist potentially "activated" Treg cells (such as those found in tumors) has not been explored, and (2) in vitro Treg suppression assay cannot recapitulate the complex interaction between $\mathrm{T}$ cells and Treg cells in vivo (60), especially since the Cbl-b ${ }^{-/-}$mice do not have the same phenotype as Treg deficient mice $(17,162-164)$. Despite these limitations, many of the in vitro observations have been consistent with in vivo properties of Cbl-b ${ }^{-/}-\mathrm{T}$ cells. For example, $\mathrm{T}$ cells deficient in Cbl-b also display a hyperactive $\mathrm{T}$ cell status in vivo. Gronski et al. (165) has demonstrated the role of Cbl-b in regulating $\mathrm{T}$ cell activation threshold, as mice deficient in Cbl-b were more sensitive to antigen-induced $\mathrm{T}$ cell stimulation resulting in autoimmunity. Lastly, Adams et al. (141) has demonstrated the role of Cbl-b in $\mathrm{CD}^{+} \mathrm{T}$ cell resistance to Treg cells in vivo through a graft-vs.-host disease model, where adoptively transferred Treg cells fail to suppress Cbl-b ${ }^{-/-} \mathrm{CD}^{+} \mathrm{T}$ cells in vivo. However, the mechanism by which Cbl- $\mathrm{b}^{-/-} \mathrm{T}$ cells resist Treg cell suppression has not been investigated in these studies.

$\mathrm{T}$ cells deficient in Cbl-b have also been studied in the context of enhancing tumor immune surveillance and antitumor immunity. Cbl-b deficiency augments anti-tumor $\mathrm{T}$ cell responses in both genetically engineered and transplanted tumor models (161, 166-168). Loeser et al. (161) and Chiang et al. (166) provide evidence showing a greater infiltration of $\mathrm{CD}^{+} \mathrm{T}$ cells using $\mathrm{TC}-1$ and EL4/EG7 transplantable tumors in Cbl-b deficient mice. In both circumstances, $\mathrm{CD} 4^{+}$ effector $\mathrm{T}$ cell infiltration did not increase. Interestingly, 
despite the increased infiltration of Treg cells in the tumors from Cbl-b deficient mice, $\mathrm{T}$ cells were able to either reject or attenuate tumor growth. A similar observation has been made when Cbl-b deficient mice were crossed with ataxia telangiectasia mutated (ATM) deficient mice, which attenuated the spontaneous development of lymphoid tumors and increased overall survival, demonstrating a robust anti-tumor immunity against genetically engineered tumor model (166). Although further investigation is required to understand how Cbl-b deficient $\mathrm{T}$ cells enhance anti-tumor immunity, one of the proposed mechanisms include insensitivity to TGF- $\beta$ receptor signaling. Gruber et al. (158) suggested that Cbl-b deficiency promotes spontaneous rejection of TC-1 tumors, whereas Cbl$\mathrm{b}^{-/-}$mice crossed with $\mathrm{CD} 4^{\mathrm{Cre}}-\mathrm{SMAD}^{\mathrm{fl} / \mathrm{fl}}$ mice abrogates anti-tumor immunity, thus highlighting the importance of Cbl$\mathrm{b}$ deficient $\mathrm{T}$ cells in anti-tumor immunity and the ability of these $\mathrm{T}$ cells to potentially overcome TGF- $\beta$ receptor signaling. Lastly, in all of the previously described studies, whether Cbl$\mathrm{b}$ deficient $\mathrm{T}$ cells resist the suppressive effects of Treg cells to enhance anti-tumor immunity has not been shown in vivo.

\section{TLR-MyD88-TRAF6 Axis}

Evidence suggests that TLR signaling also play an important role in T cell resistance to Treg cells. Pasare and Medzhitov (169) suggested that TLR4 and TLR9-mediated stimulation of DCs and the subsequent increase in IL- 6 production by DCs render T cells resistant to the effects of Treg cells. However, this particular study presumed that TLR signaling was restricted to DCs. TLRs can be expressed by effector T cells and Treg cells, and play an important role in their cellular activation and survival $(170,171)$. Although our understanding of TLR signaling pathways in T cells is rather limited, TLRs expressed on $\mathrm{T}$ cells likely function similar to co-stimulatory receptors which trigger the downstream MyD88 signaling pathway as well as the PI3K/Akt signaling pathway (172). TLR signaling in T cells may also play an important role in rendering $\mathrm{T}$ cells refractory to Treg cell-mediated suppression. For example, TLR9 stimulation of murine $\mathrm{T}$ cells enhances the PI3K/Akt signaling pathway and MyD88-dependent IL-2 production; TLR9 signaling also renders $\mathrm{T}$ cells resistant to the suppressive effects of Treg cells $(173,174)$. Downstream of TLRs, MyD88 interacts with IRAK1 and IRAK4, modulating the activities of an E3 ubiquitin ligase TRAF6 which may contribute to NFKB signaling (175). However, the role of TRAF6 in T cells is far more complex and contradictory, which is exemplified through a study suggesting that TRAF6 also serves as a negative regulator of $\mathrm{T}$ cell function (176). In this study, T cells deficient in TRAF6 display enhanced T cell activation, CD28-indpendent stimulation and resistance to Treg cell-mediated suppression (176). Although TLR signaling can promote $\mathrm{T}$ cell resistance to Treg cells, the precise molecular mechanism remains yet to be elucidated. It is worth noting that TLR stimulation of $\mathrm{T}$ cells increases cytokine production $(173,177)$, thus future studies should delineate the effect of TLR-MyD88 signaling vs. subsequently induced cytokines in generating resistance to Treg cells. Lastly, it is also crucial to evaluate the effect of TLR signaling on regulatory T cells which also express TLRs (170). The role of TLR signaling on Treg cell function requires further investigation and clarification since it can both abrogate and enhance Treg cell functions (170, 177-179). A recent study suggested that TLR signaling on regulatory T cells induces PI3K/Akt/mTORC1 signaling which subsequently increases glycolysis and GLUT1 expression, which in turn interferes with FoxP3 expression and the suppressive ability of Treg cells (180). However, increased Treg cell function observed in several studies could also occur indirectly as a result of enhanced $\mathrm{T}$ cell stimulation and IL-2 secretion, which can subsequently promote Treg cell function.

Although TLR agonists can improve anti-tumor immune responses by enhancing $\mathrm{T}$ cell function and/or stimulating APC maturation, they may also act on other immune cells and cancer cells to impact anti-tumor immunity $(181,182)$. Therefore, it would be difficult to specifically target TLRs to promote resistance to Treg cells.

\section{TNF Family Members}

TNF family members such as GITR, OX40, and 4-1BB on T cells can also be targeted to induce $\mathrm{T}$ cell resistance to Treg cells (183188). Evidence suggests that amplification of GITR signaling through the use of agonistic antibody, DTA-1, enhances T cell stimulation in the presence of Treg cells both in vitro and in vivo $(184,189,190)$. However, GITR is also highly expressed on Treg cells and studies suggests that a GITR agonist attenuates Treg cell stability $(191,192)$. In contrast, in vivo administration of nondepleting Fc-GITR-L induces context-dependent modulation of Treg cell activities (193). Further work is required to precisely understand the effect of GITR signaling on Treg cells. Although the role of GITR agonist in the interaction between $\mathrm{T}$ cell and Treg cell is unclear in vivo, Stephens et al. (184) suggested that GITR signaling directly acts on T cells to resist the suppressive effects of Treg cells in vitro. Lastly, a GITR agonist antibody (DTA-1) has demonstrated its potential in enhancing $\mathrm{CD}^{+} \mathrm{T}$ cell response and reducing intra-tumoral Treg cell activities using transplantable tumor models including the B16 melanoma model (190, 192, 194). In summary, administration of TNF-family receptor agonists such as those targeting GITR promote $\mathrm{T}$ cell response in the presence of Treg cells and contribute to enhanced anti-tumor immunity. However, the mechanism behind how TNF family receptor signaling renders $\mathrm{T}$ cells refractory to Treg cell-mediated suppression is poorly understood.

\section{Cytokine Networks}

Most intracellular molecules and surface receptor targets which render $\mathrm{T}$ cells resistant to inhibition by Treg cells often promote the secretion of a high quantity of $\mathrm{T}$ cell stimulatory cytokines. This is demonstrated by the early study conducted by Pasare and Medzhitov (169), which showed that LPS stimulation of DCs leads to increased IL-6 which plays an important role in T cell resistance to regulatory T cells $(169,195)$. Similarly, inhibition of Cbl-b or activation of GITR signaling increases IL-2 production by $\mathrm{T}$ cells both in vitro and in vivo $(167,168,183)$. Increased cytokine production is often perceived as an indicator of Treg resistance. However, evidence suggests that various cytokines themselves can directly drive T cell resistance to Treg cells (195199). This raises a question-to what extent do cytokines play a role in Treg resistance? Both T cells and Treg cells are susceptible 
to cytokine receptor-mediated signaling, and therefore the effect of cytokines in both cell compartment must be considered.

Soluble mediators such as cytokines can modulate a powerful receptor-mediated $\mathrm{T}$ cell signaling required for cellular proliferation, survival, and resistance to Treg cell-mediated suppression. Cytokines including interferons (IFN $\gamma$ and IFN $\alpha$ ), those binding to receptors that include the common $\gamma$-chain (IL-2, IL-4, IL-7, IL-15, IL-21, and TSLP), gp130 receptor cytokines (IL-6) and IL-1 receptor cytokines (IL-1 $\beta$ and IL-18) employ diverse combinations of intracellular signaling pathways such as the JAK/STAT signaling pathways to promote $\mathrm{T}$ cell differentiation and effector functions (200-202). Many studies have also highlighted the role of $\mathrm{T}$ cell stimulatory cytokines, in particular IL-1 $\beta$, IL-2, IL-4, IL-6, IL-7, IL-15, and IL-21, as central drivers of $\mathrm{T}$ cell stimulation in the presence of Treg cells (87, 195-198, 203-205). Some of these T cell stimulatory cytokines may induce $\mathrm{T}$ cell proliferation and survival in the presence of Treg cells by common mechanisms, because their receptors share overlapping downstream signaling pathways, but the mechanism by which each of these cytokines support $\mathrm{T}$ cell proliferation in the co-cultures has not been fully clarified.

One of the first cytokines reported to enhance $\mathrm{T}$ cell proliferation in the presence of Treg cells in vitro is IL-2 (199). Upon high-affinity quaternary IL-2-IL2R complex formation, tyrosine kinases JAK1, and JAK3 also initiate a STAT1, STAT3, and STAT5-dependent response, along with the induction of the PI3K signaling pathway $(201,202)$. Although IL-2 serves as a potent inducer of $\mathrm{T}$ cell proliferation in Treg suppression assays, there is no strong evidence suggesting that the signaling pathways downstream of IL-2 directly attenuates the inhibitory signals induced by Treg cells. Instead, excess IL-2 could enable $\mathrm{T}$ cells to overcome Treg cell-mediated cytokine deprivation (87, 199), which, despite being somewhat controversial, may be an important suppressive mechanism utilized by Treg cells $(89,91)$. Lastly, many T cell stimulatory cytokines including IL-2, IL-7, and IL-15 play an important role in enhancing anti-tumor immunity (206-208), but whether or not these cytokines render $\mathrm{T}$ cells resistant to the suppressive effects of Treg cells in the context of anti-tumor immunity is unclear.

When evaluating the role of cytokines in rendering $\mathrm{T}$ cells resistant to Treg cells, the effect of cytokine signaling must also be evaluated on Treg cells. Under a circumstance where $\mathrm{T}$ cell stimulatory cytokine destabilizes Treg cell function, it becomes challenging to determine whether $\mathrm{T}$ cell resistance to Treg cells play an important role in the observed $\mathrm{T}$ cell proliferation in the presence of Treg cells. Although poorly understood, Treg cells display phenotypic and functional plasticity in response to certain cytokines; $\mathrm{T}$ cell stimulatory cytokines may mediate the downregulation of FoxP3 or conversion of Treg cells into conventional $\mathrm{T}$ cells $(209,210)$. This is exemplified through a study which demonstrates the ability of IL-4 to convert FoxP $^{+}$cells into effector $\mathrm{CD}^{+}{ }^{+} \mathrm{T}$ cells, thereby undermining oral tolerance (211). PI3K signaling pathway is regulated by PTEN expression in Treg cells to prevent loss of Treg cell stability $(212,213)$, however, IL-4 may disrupt this process by enhancing PI3K signaling. Several other cytokines including IL-21 also antagonize Treg cell proliferation and reduce the frequency of Treg cells (214). However, a study conducted by Attridge et al. (215) suggest that IL-21 may act on T cells to limit IL-2 production which subsequently impairs Treg cell homeostasis. Furthermore, a recent study conducted by Overacre-Delgoffe et al. (132) suggests that attenuating Nrp-1 signaling on intra-tumoral Treg cells induces increased secretion of IFN $\gamma$ by the Treg cells, and IFN $\gamma$ subsequently acts on nearby regulatory T cells to "destabilize" their suppressive phenotype. In contrast to the previously discussed examples which destabilize FoxP3 expression in Treg cells, a few cytokines binding to receptors that include the common $\gamma$-chain can enhance Treg cell proliferation and function. For instance, adding IL-2 enhances T cell proliferation, despite also stimulating Treg cells $(87,199)$.

Another possibility to be considered in cytokine-induced $\mathrm{T}$ cell resistance to Treg cells in vitro is proliferation and expansion of $\mathrm{T}$ cell quantity as the mechanism of Treg cell resistance, which should be distinguished from the ability to negate immunosuppressive signals. Especially in a murine in vitro system where Treg cell proliferation is limited, the capacity of $\mathrm{T}$ cells to proliferate may be independent of their ability to negate immunosuppressive signals by Treg cells. In other words, these $\mathrm{T}$ cells stimulated with cytokines may be equally susceptible to Treg cell-mediated suppression, but by increasing proliferation and quantity of $\mathrm{T}$ cells, the suppressive effect of Treg cells may become less apparent.

\section{Observations From Current Clinical Studies}

One of the primary objectives of cancer immune therapy is to modulate anti-tumor $\mathrm{T}$ cell properties to reduce the tumor burden. However, the presence of immunoregulatory cells such as Treg cells are likely to interfere with the anti-tumor $\mathrm{T}$ cell response $(9,60,216)$. Thus, overcoming the suppressive effects of Treg cells to potentially enhance anti-tumor $\mathrm{T}$ cell response in patients is a strategy currently under investigation. Many of the current clinical studies involve targeting surface receptors on Treg cells such as CD25, CTLA-4, and CCR4 (110, 124, 217).

However, clinical studies have not focused on rendering $\mathrm{T}$ cells resistant to the suppressive effects of Treg cells. Interestingly, some of the existing treatment methods may already foster $\mathrm{T}$ cells resistant to Treg cells. For instance, high dose IL-2 is part of the protocol for adoptive TIL therapy against metastatic melanoma, despite actively expanding immunosuppressive ICOS ${ }^{+}$Treg cells $(55,218-221)$, supporting the possibility that high-dose IL-2 is successful because it may render TIL resistant to Treg cell suppression. Therefore, the dosage of systemic IL-2 administration in these studies may play an important role in promoting the $\mathrm{T}$ cell response against the tumor, since low dose IL-2 has been used to preferentially expand Treg cells to attenuate the progression of human autoimmune diseases $(222,223)$. To avoid IL-2mediated expansion of immunosuppressive Treg cells, a preclinical study conducted by Charych et al. (224) suggested that NKTR-214, a biologic drug containing an IL-2 core conjugated to 6 releasable polyethylene glycol chains, can be utilized to preferentially induce IL-2 signaling on T cells while reducing the expansion of Treg cells. In this study, the ability of NKTR214 to preferentially bind to IL-2R $\beta$ over IL-2R $\alpha$ induces a 
greater $\mathrm{CD}^{+} \mathrm{T}$ cell to Treg cell ratio, greater exposure to IL2 in the tumor and a more robust anti-tumor immunity in comparison to aldesleukin. This particular approach is currently in clinical trials. Several other therapeutic strategies involving modified IL-2 biologics also suggest similarly promising results in their ability to preferentially enhance $\mathrm{T}$ cells over Treg cells $(225,226)$.

\section{CONCLUDING REMARKS}

Regulatory $\mathrm{T}$ cells can be potent regulators of anti-tumor immunity, and numerous strategies have been proposed to reverse the suppressive effects of Treg cells. One promising approach involves rendering $\mathrm{T}$ cells resistant to the suppressive effects of Treg cells. Resistance to Treg cells can be achieved through modulation of intracellular molecules, co-stimulatory surface receptors or cytokines, all of which may act through

\section{REFERENCES}

1. Topalian SL, Drake CG, Pardoll DM. Immune checkpoint blockade: a common denominator approach to cancer therapy. Cancer Cell. (2015) 27:450-61. doi: 10.1016/J.CCELL.2015.03.001

2. Khalil DN, Smith EL, Brentjens RJ, Wolchok JD. The future of cancer treatment: immunomodulation, CARs and combination immunotherapy. Nat Rev Clin Oncol. (2016) 13:273-90. doi: 10.1038/nrclinonc.2016.25

3. Fesnak AD, Levine BL, June CH. Engineered T cells: the promise and challenges of cancer immunotherapy. Nat Rev Cancer. (2016) 16:566-81. doi: $10.1038 /$ nrc.2016.97

4. Gajewski TF, Meng Y, Blank C, Brown I, Kacha A, Kline J, et al. Immune resistance orchestrated by the tumor microenvironment. Immunol Rev. (2006) 213:131-45. doi: 10.1111/j.1600-065X.2006.00442.x

5. Quail DF, Joyce JA. Microenvironmental regulation of tumor progression and metastasis. Nat Med. (2013) 19:1423-37. doi: 10.1038/nm.3394

6. Binnewies M, Roberts EW, Kersten K, Chan V, Fearon DF, Merad M, et al. Understanding the tumor immune microenvironment (TIME) for effective therapy. Nat Med. (2018) 24:541-50. doi: 10.1038/s41591-018-0014-x

7. Sakaguchi S, Yamaguchi T, Nomura T, Ono M. Regulatory T cells and immune tolerance. Cell. (2008) 133:775-87. doi: 10.1016/j.cell.2008.05.009

8. Sakaguchi S, Miyara M, Costantino CM, Hafler DA. FOXP3 ${ }^{+}$regulatory T cells in the human immune system. Nat Rev Immunol. (2010) 10:490-500. doi: $10.1038 /$ nri2785

9. Nishikawa H, Sakaguchi S. Regulatory T cells in cancer immunotherapy. Curr Opin Immunol. (2014) 27:1-7. doi: 10.1016/j.coi.2013.12.005

10. Sakaguchi S, Sakaguchi N, Asano M, Itoh M, Toda M. Immunologic selftolerance maintained by activated T cells expressing IL-2 receptor a-chains (CD25) breakdown of a single mechanism of self-tolerance causes various autoimmune diseases. J Immunol. (1995) 155:1151-64.

11. Woo EY, Chu CS, Goletz TJ, Schlienger K, Yeh H, Coukos G, et al. Regulatory CD4 CD25 T cells in tumors from patients with early-stage non-small cell lung cancer and late-stage ovarian cancer. Cancer Res. (2001) 61:4766-72.

12. Liyanage UK, Moore TT, Joo H-G, Tanaka Y, Herrmann V, Doherty G, et al. Prevalence of regulatory $\mathrm{T}$ cells is increased in peripheral blood and tumor microenvironment of patients with pancreas or breast adenocarcinoma. $J$ Immunol. (2002) 169:2756-61. doi: 10.4049/jimmunol.169.5.2756

13. Gray CP, Arosio P, Hersey P. Association of increased levels of heavy-chain ferritin with increased CD4 CD25 regulatory T-cell levels in patients with melanoma. Clin Cancer Res. (2003) 9:2551-9.

14. Viguier M, Lemaître F, Verola O, Cho M-S, Gorochov G, Dubertret $\mathrm{L}$, et al. Foxp3 expressing $\mathrm{CD} 4^{+} \mathrm{CD} 25^{\text {high }}$ regulatory $\mathrm{T}$ cells are overrepresented in human metastatic melanoma lymph nodes and inhibit partially redundant or overlapping mechanisms. Concepts discussed in this review primarily focus on strategies to manipulate the balance between $\mathrm{T}$ cells and Treg cells. However, future studies should validate these concepts in the context of anti-tumor immunity and focus on recapitulating many of these observations using primary human $\mathrm{T}$ cells.

\section{AUTHOR CONTRIBUTIONS}

All authors listed have made a substantial, direct and intellectual contribution to the work, and approved it for publication.

\section{FUNDING}

Canadian Institute for Health Research Grant (Foundation Scheme - FDN 143220). the function of infiltrating $\mathrm{T}$ cells. J Immunol. (2004) 173:1444-53. doi: 10.4049/jimmunol.173.2.1444

15. Hori S, Nomura T, Sakaguchi S. Control of regulatory T cell development by the transcription factor Foxp3. Science. (2003) 299:1058-61. doi: $10.1126 /$ science. 1079490

16. Fontenot JD, Gavin MA, Rudensky AY. Foxp3 programs the development and function of $\mathrm{CD}^{+}{ }^{+} \mathrm{CD} 25^{+}$regulatory T cells. Nat Immunol. (2003) 4:330-6. doi: 10.1038/ni904

17. Khattri R, Cox T, Yasayko S-A, Ramsdell F. An essential role for Scurfin in $\mathrm{CD} 4{ }^{+} \mathrm{CD} 25^{+}$T regulatory cells. Nat Immunol. (2003) 4:337-42. doi: $10.1038 /$ ni909

18. Curiel TJ, Coukos G, Zou L, Alvarez X, Cheng P, Mottram P, et al. Specific recruitment of regulatory $\mathrm{T}$ cells in ovarian carcinoma fosters immune privilege and predicts reduced survival. Nat Med. (2004) 10:942-9. doi: $10.1038 / \mathrm{nm} 1093$

19. Bates GJ, Fox SB, Han C, Leek RD, Garcia JF, Harris AL, et al. Quantification of regulatory $\mathrm{T}$ cells enables the identification of high-risk breast cancer patients and those at risk of late relapse. J Clin Oncol. (2006) 24:5373-80. doi: 10.1200/JCO.2006.05.9584

20. Shou J, Zhang Z, Lai Y, Chen Z, Huang J. Worse outcome in breast cancer with higher tumor-infiltrating $\mathrm{FOXP}^{+}$Tregs : a systematic review and meta-analysis. BMC Cancer. (2016) 16:687. doi: 10.1186/s12885-016-2732-0

21. Leffers N, Gooden MJM, de Jong RA, Hoogeboom B-N, ten Hoor $\mathrm{KA}$, Hollema $\mathrm{H}$, et al. Prognostic significance of tumor-infiltrating T-lymphocytes in primary and metastatic lesions of advanced stage ovarian cancer. Cancer Immunol Immunother. (2009) 58:449-59. doi: 10.1007/s00262-008-0583-5

22. Correale P, Rotundo MS, Del Vecchio MT, Remondo C, Migali C, Ginanneschi C, et al. Regulatory $\left(\mathrm{FoxP}^{+}\right.$) T-cell tumor infiltration is a favorable prognostic factor in advanced colon cancer patients undergoing chemo or chemoimmunotherapy. J Immunother. (2010) 33:43541. doi: 10.1097/CJI.0b013e3181d32f01

23. Yeong J, Thike AA, Lim JCT, Lee B, Li H, Wong S-C, et al. Higher densities of Foxp $3^{+}$regulatory $\mathrm{T}$ cells are associated with better prognosis in triple-negative breast cancer. Breast Cancer Res Treat. (2017) 163:21-35. doi: 10.1007/s10549-017-4161-4

24. West NR, Kost SE, Martin SD, Milne K, deLeeuw RJ, Nelson BH, et al. Tumour-infiltrating $\mathrm{FOXP}^{+}$lymphocytes are associated with cytotoxic immune responses and good clinical outcome in oestrogen receptornegative breast cancer. Br J Cancer. (2013) 108:155-62. doi: 10.1038/bjc. 2012.524

25. Saito T, Nishikawa H, Wada H, Nagano Y, Sugiyama D, Atarashi K, et al. Two FOXP3 ${ }^{+} \mathrm{CD}^{+}{ }^{+} \mathrm{T}$ cell subpopulations distinctly control the prognosis of colorectal cancers. Nat Med. (2016) 22:679-84. doi: 10.1038/nm.4086 
26. Tran DQ, Ramsey H, Shevach EM. Induction of FOXP3 expression in naive human $\mathrm{CD}^{+} \mathrm{FOXP} 3 \mathrm{~T}$ cells by $\mathrm{T}$-cell receptor stimulation is transforming growth factor-beta dependent but does not confer a regulatory phenotype. Blood. (2007) 110:2983-90. doi: 10.1182/blood-2007-06094656

27. Miyara M, Yoshioka Y, Kitoh A, Shima T, Wing K, Niwa A, et al. Functional delineation and differentiation dynamics of human $\mathrm{CD} 4^{+} \mathrm{T}$ cells expressing the foxp3 transcription factor. Immunity. (2009) 30:899-911. doi: 10.1016/J.IMMUNI.2009.03.019

28. Baron U, Floess S, Wieczorek G, Baumann K, Grützkau A, Dong J, et al. DNA demethylation in the humanFOXP3 locus discriminates regulatory $\mathrm{T}$ cells from activated FOXP3 ${ }^{+}$conventional T cells. Eur J Immunol. (2007) 37:2378-89. doi: 10.1002/eji.200737594

29. Wieczorek G, Asemissen A, Model F, Turbachova I, Floess S, Liebenberg V, et al. Quantitative DNA methylation analysis of FOXP3 as a new method for counting regulatory $\mathrm{T}$ cells in peripheral blood and solid tissue. Cancer Res. (2009) 69:599-608. doi: 10.1158/0008-5472.CAN-08-2361

30. Strauss L, Bergmann C, Szczepanski M, Gooding W, Johnson JT, Whiteside TL. A unique subset of $\mathrm{CD}^{+} \mathrm{CD} 25^{\text {high }}$ Foxp $^{+} \mathrm{T}$ cells secreting interleukin-10 and transforming growth factor-B1 mediates suppression in the tumor microenvironment. Clin Cancer Res. (2007) 13:4345-54. doi: 10.1158/1078-0432.CCR-07-0472

31. Toker A, Nguyen LT, Stone SC, Cindy Yang S, Rachel Katz S, Shaw PA, et al. Regulatory $\mathrm{T}$ cells in ovarian cancer are characterized by a highly activated phenotype distinct from that in melanoma. Clin Cancer Res. (2018) 24:5685-96. doi: 10.1158/1078-0432.CCR-18-0554

32. Yamaguchi T, Hirota K, Nagahama K, Ohkawa K, Takahashi T, Nomura $\mathrm{T}$, et al. Control of immune responses by antigen-specific regulatory $\mathrm{T}$ cells expressing the folate receptor. Immunity. (2007) 27:145-59. doi: 10.1016/J.IMMUNI.2007.04.017

33. Coe D, Begom S, Addey C, White M, Dyson J, Chai J-G. Depletion of regulatory $\mathrm{T}$ cells by anti-GITR $\mathrm{mAb}$ as a novel mechanism for cancer immunotherapy. Cancer Immunol Immunother. (2010) 59:1367-77. doi: 10.1007/s00262-010-0866-5

34. Klages K, Mayer CT, Lahl K, Loddenkemper C, Teng MWL, Ngiow SF, et al. Selective depletion of Foxp $3^{+}$regulatory $\mathrm{T}$ cells improves effective therapeutic vaccination against established melanoma. Cancer Res. (2010) 70:7788-99. doi: 10.1158/0008-5472.CAN-10-1736

35. Arce Vargas F, Furness AJS, Solomon I, Joshi K, Mekkaoui L, Lesko MH, et al. Fc-optimized anti-CD25 depletes tumor-infiltrating regulatory $\mathrm{T}$ cells and synergizes with PD-1 blockade to eradicate established tumors. Immunity. (2017) 46:577-86. doi: 10.1016/j.immuni.2017.03.013

36. Antony PA, Piccirillo CA, Akpinarli A, Finkelstein SE, Speiss PJ, Surman $\mathrm{DR}$, et al. $\mathrm{CD}^{+} \mathrm{T}$ cell immunity against a tumor/self-antigen is augmented by $\mathrm{CD}^{+} \mathrm{T}$ helper cells and hindered by naturally occurring $\mathrm{T}$ regulatory cells. J Immunol. (2005) 174:2591-601. doi: 10.4049/JIMMUNOL.174. 5.2591

37. Yao X, Ahmadzadeh M, Lu Y-C, Liewehr DJ, Dudley ME, Liu F, et al. Levels of peripheral $\mathrm{CD}^{+}{ }^{+} \mathrm{FoxP}^{+}{ }^{+}$regulatory $\mathrm{T}$ cells are negatively associated with clinical response to adoptive immunotherapy of human cancer. Blood. (2012) 119:5688-96. doi: 10.1182/blood-2011-10-386482

38. O’Rourke DM, Nasrallah MP, Desai A, Melenhorst JJ, Mansfield K, Morrissette JJD, et al. A single dose of peripherally infused EGFRvIIIdirected CAR T cells mediates antigen loss and induces adaptive resistance in patients with recurrent glioblastoma. Sci Transl Med. (2017) 9:eaaa0984. doi: 10.1126/scitranslmed.aaa0984

39. Woods DM, Ramakrishnan R, Laino AS, Berglund A, Walton K, Betts $\mathrm{BC}$, et al. Decreased suppression and increased phosphorylated STAT3 in regulatory $\mathrm{T}$ cells are associated with benefit from adjuvant $\mathrm{PD}-1$ blockade in resected metastatic melanoma. Clin Cancer Res. (2018) 24:6236-47. doi: 10.1158/1078-0432.CCR-18-1100

40. Alsaab HO, Sau S, Alzhrani R, Tatiparti K, Bhise K, Kashaw SK, et al. PD1 and PD-L1 checkpoint signaling inhibition for cancer immunotherapy: mechanism, combinations, and clinical outcome. Front Pharmacol. (2017) 8:561. doi: 10.3389/fphar.2017.00561

41. Ribas A, Shin DS, Zaretsky J, Frederiksen J, Cornish A, Avramis E, et al. PD-1 blockade expands intratumoral memory T cells. Cancer Immunol Res. (2016) 4:210. doi: 10.1158/2326-6066.CIR-15-0210
42. Francisco LM, Sage PT, Sharpe AH. The PD-1 pathway in tolerance and autoimmunity. Immunol Rev. (2010) 236:219-42. doi: 10.1111/j.1600-065X.2010.00923.x

43. De Simone M, Arrigoni A, Rossetti G, Gruarin P, Ranzani V, Politano C, et al. Transcriptional landscape of human tissue lymphocytes unveils uniqueness of tumor-infiltrating T regulatory cells. Immunity. (2016) 45:1135-47. doi: 10.1016/J.IMMUNI.2016.10.021

44. Plitas G, Konopacki C, Wu K, Bos PD, Morrow M, Putintseva EV, et al. Regulatory $\mathrm{T}$ cells exhibit distinct features in human breast cancer. Immunity. (2016) 45:1122-34. doi: 10.1016/j.immuni.2016.10.032

45. Wang W, Lau R, Yu D, Zhu W, Korman A, Weber J. PD1 blockade reverses the suppression of melanoma antigen-specific CTL by $\mathrm{CD} 4^{+} \mathrm{CD} 25^{\mathrm{Hi}}$ regulatory $\mathrm{T}$ cells. Int Immunol. (2009) 21:1065-77. doi: 10.1093/intimm/dxp072

46. Wang C, Thudium KB, Han M, Wang X-T, Huang H, Feingersh D, et al. In vitro characterization of the anti-PD-1 antibody nivolumab, BMS-936558, and in vivo toxicology in non-human primates. Cancer Immunol Res. (2014) 2:846-56. doi: 10.1158/2326-6066.CIR-14-0040

47. Toor SM, Syed Khaja AS, Alkurd I, Elkord E. In-vitro effect of pembrolizumab on different T regulatory cell subsets. Clin Exp Immunol. (2018) 191:189-97. doi: 10.1111/cei.13060

48. Toor SM, Sasidharan Nair V, Pfister G, Elkord E. Effect of pembrolizumab on $\mathrm{CD}^{+} \mathrm{CD}_{25}{ }^{+}, \mathrm{CD}^{+} \mathrm{LAP}^{+}$and $\mathrm{CD} 4^{+} \mathrm{TIM}-3^{+}$T cell subsets. Clin Exp Immunol. (2019). doi: 10.1111/cei.13264. [Epub ahead of print].

49. Chen X, Fosco D, Kline DE, Meng L, Nishi S, Savage PA, et al. PD1 regulates extrathymic regulatory T-cell differentiation. Eur J Immunol. (2014) 44:2603-16. doi: 10.1002/eji.201344423

50. Francisco LM, Salinas VH, Brown KE, Vanguri VK, Freeman GJ, Kuchroo VK, et al. PD-L1 regulates the development, maintenance, and function of induced regulatory T cells. J Exp Med. (2009) 206:3015-29. doi: 10.1084/jem.20090847

51. Oweida A, Hararah MK, Phan A, Binder D, Bhatia S, Lennon S, et al. Resistance to radiotherapy and PD-L1 blockade is mediated by TIM-3 upregulation and regulatory T-cell infiltration. Clin Cancer Res. (2018) 24:5368-80. doi: 10.1158/1078-0432.CCR-18-1038

52. Dodagatta-Marri E, Meyer DS, Reeves MQ, Paniagua R, To MD, Binnewies $\mathrm{M}$, et al. $\alpha-\mathrm{PD}-1$ therapy elevates Treg/Th balance and increases tumor cell pSmad 3 that are both targeted by $\alpha$-TGF $\beta$ antibody to promote durable rejection and immunity in squamous cell carcinomas. J Immunother Cancer. (2019) 7:62. doi: 10.1186/s40425-018-0493-9

53. Rosenberg SA, Restifo NP. Adoptive cell transfer as personalized immunotherapy for human cancer. Science. (2015) 348:62-8. doi: 10.1126/science.aaa4967

54. Zhang C, Wang Z, Yang Z, Wang M, Li S, Li Y, et al. Phase I escalating-dose trial of CAR-T therapy targeting $\mathrm{CEA}^{+}$metastatic colorectal cancers. $\mathrm{Mol}$ Ther. (2017) 25:1248-58. doi: 10.1016/j.ymthe.2017.03.010

55. Sim GC, Martin-Orozco N, Jin L, Yang Y, Wu S, Washington E, et al. IL-2 therapy promotes suppressive ICOS ${ }^{+}$Treg expansion in melanoma patients. J Clin Invest. (2014) 124:99-110. doi: 10.1172/JCI46266

56. Baba J, Watanabe S, Saida Y, Tanaka T, Miyabayashi T, Koshio J, et al. Depletion of radio-resistant regulatory $\mathrm{T}$ cells enhances antitumor immunity during recovery from lymphopenia. Blood. (2012) 120:2417-27. doi: 10.1182/blood-2012-02-411124

57. Enblad G, Karlsson H, Gammelgård G, Wenthe J, Lövgren T, Amini RM, et al. A phase I/IIa trial using CD19-targeted third-generation CAR T cells for lymphoma and leukemia. Clin Cancer Res. (2018) 24:6185-94. doi: 10.1158/1078-0432.CCR-18-0426

58. Park JH, Geyer MB, Brentjens RJ. CD19-targeted CAR T-cell therapeutics for hematologic malignancies: interpreting clinical outcomes to date. Blood. (2016) 127:3312-20. doi: 10.1182/blood-2016-02-629063

59. Vignali DAA, Collison LW, Workman CJ. How regulatory T cells work. Nat Rev Immunol. (2008) 8:523-32. doi: 10.1038/nri2343

60. Shevach EM. Foxp $3^{+}$T regulatory cells: still many unanswered QuestionsA perspective after 20 years of study. Front Immunol. (2018) 9:1-9. doi: 10.3389/fimmu.2018.01048

61. Tran DQ, Shevach EM. Therapeutic potential of FOXP3 ${ }^{+}$regulatory T cells and their interactions with dendritic cells. Hum Immunol. (2009) 70:294-9. doi: 10.1016/j.humimm.2009.02.007 
62. Wing K, Onishi Y, Prieto-Martin P, Yamaguchi T, Miyara M, Fehervari Z, et al. CTLA-4 control over Foxp $3^{+}$regulatory T cell function. Science. (2008) 322:271-5. doi: 10.1126/science.1160062

63. Onishi Y, Fehervari Z, Yamaguchi T, Sakaguchi S. Foxp $3^{+}$natural regulatory $\mathrm{T}$ cells preferentially form aggregates on dendritic cells in vitro and actively inhibit their maturation. Proc Natl Acad Sci USA. (2008) 105:10113-8. doi: 10.1073/pnas.0711106105

64. Wing K, Yamaguchi T, Sakaguchi S. Cell-autonomous and -non-autonomous roles of CTLA-4 in immune regulation. Trends Immunol. (2011) 32:428-33. doi: 10.1016/J.IT.2011.06.002

65. Qureshi OS, Zheng Y, Nakamura K, Attridge K, Manzotti C, Schmidt $\mathrm{EM}$, et al. Trans-endocytosis of CD80 and CD86: a molecular basis for the cell-extrinsic function of CTLA-4. Science. (2011) 332:600-3. doi: 10.1126/science.1202947

66. Grohmann U, Orabona C, Fallarino F, Vacca C, Calcinaro F, Falorni A, et al. CTLA-4-Ig regulates tryptophan catabolism in vivo. Nat Immunol. (2002) 3:1097-101. doi: 10.1038/ni846

67. Dejean AS, Beisner DR, Ch'en IL, Kerdiles YM, Babour A, Arden KC, et al. Transcription factor Foxo3 controls the magnitude of $\mathrm{T}$ cell immune responses by modulating the function of dendritic cells. Nat Immunol. (2009) 10:504-13. doi: 10.1038/ni.1729

68. Paterson AM, Lovitch SB, Sage PT, Juneja VR, Lee Y, Trombley JD, et al. Deletion of CTLA-4 on regulatory $\mathrm{T}$ cells during adulthood leads to resistance to autoimmunity. J Exp Med. (2015) 212:1603-21. doi: $10.1084 /$ jem. 20141030

69. Chen J, Ganguly A, Mucsi AD, Meng J, Yan J, Detampel P, et al. Strong adhesion by regulatory $\mathrm{T}$ cells induces dendritic cell cytoskeletal polarization and contact-dependent lethargy. J Exp Med. (2017) 214:327-38. doi: $10.1084 /$ jem.20160620

70. Grossman WJ, Pham CT, Ley TJ, Kemper C, Atkinson JP, Ley TJ. Granzymes A and B are not expressed in human neutrophils. Blood. (2004) 104:906-8. doi: 10.1182/blood-2004-03-0858

71. Gondek DC, Lu L-F, Quezada SA, Sakaguchi S, Noelle RJ. Cutting edge: contact-mediated suppression by $\mathrm{CD} 4{ }^{+} \mathrm{CD} 25^{+}$regulatory cells involves a granzyme B-dependent, perforin-independent mechanism. J Immunol. (2005) 174:1783-6. doi: 10.4049/JIMMUNOL.174.4.1783

72. Cao X, Cai SF, Fehniger TA, Song J, Collins LI, Piwnica-Worms DR, et al. Granzyme B and perforin are important for regulatory $\mathrm{T}$ cellmediated suppression of tumor clearance. Immunity. (2007) 27:635-46. doi: 10.1016/J.IMMUNI.2007.08.014

73. Deaglio S, Dwyer KM, Gao W, Friedman D, Usheva A, Erat A, et al. Adenosine generation catalyzed by CD39 and CD73 expressed on regulatory T cells mediates immune suppression. J Exp Med. (2007) 204:1257-65. doi: 10.1084/jem.20062512

74. O'Garra A, Vieira PL, Vieira P, Goldfeld AE. IL-10-producing and naturally occurring $\mathrm{CD}^{+}$Tregs: limiting collateral damage. J Clin Invest. (2004) 114:1372-8. doi: 10.1172/JCI23215

75. Fahlén L, Read S, Gorelik L, Hurst SD, Coffman RL, Flavell RA, et al. T cells that cannot respond to TGF-beta escape control by $\mathrm{CD} 4{ }^{+} \mathrm{CD} 25^{+}$regulatory T cells. J Exp Med. (2005) 201:737-46. doi: 10.1084/jem.20040685

76. Chen M-L, Pittet MJ, Gorelik L, Flavell RA, Weissleder R, von Boehmer $\mathrm{H}$, et al. Regulatory $\mathrm{T}$ cells suppress tumor-specific CD8 T cell cytotoxicity through TGF-beta signals in vivo. Proc Natl Acad Sci USA. (2005) 102:41924. doi: 10.1073/pnas.0408197102

77. Collison LW, Workman CJ, Kuo TT, Boyd K, Wang Y, Vignali KM, et al. The inhibitory cytokine IL-35 contributes to regulatory T-cell function. Nature. (2007) 450:566-9. doi: 10.1038/nature06306

78. Nakamura K, Kitani A, Strober W. Cell contact-dependent immunosuppression by $\mathrm{CD} 4^{+} \mathrm{CD} 25^{+}$regulatory $\mathrm{T}$ cells is mediated by cell surface-bound transforming growth factor beta. J Exp Med. (2001) 194:629-44. doi: 10.1084/jem.194.5.629

79. Rubtsov YP, Rudensky AY. TGF $\beta$ signalling in control of T-cell-mediated self-reactivity. Nat Rev Immunol. (2007) 7:443-53. doi: 10.1038/nri2095

80. Thomas DA, Massagué J. TGF- $\beta$ directly targets cytotoxic T cell functions during tumor evasion of immune surveillance. Cancer Cell. (2005) 8:369-80. doi: 10.1016/J.CCR.2005.10.012

81. Piccirillo CA, Letterio JJ, Thornton AM, McHugh RS, Mamura M, Mizuhara $\mathrm{H}$, et al. $\mathrm{CD} 4^{+} \mathrm{CD} 25^{+}$regulatory $\mathrm{T}$ cells can mediate suppressor function in the absence of transforming growth factor betal production and responsiveness. J Exp Med. (2002) 196:237-46. doi: 10.1084/JEM.20020590

82. Chaudhry A, Samstein RM, Treuting P, Liang Y, Pils MC, Heinrich J$\mathrm{M}$, et al. Interleukin-10 signaling in regulatory $\mathrm{T}$ cells is required for suppression of Th17 cell-mediated inflammation. Immunity. (2011) 34:56678. doi: 10.1016/j.immuni.2011.03.018

83. Dennis KL, Blatner NR, Gounari F, Khazaie K. Current status of interleukin10 and regulatory T-cells in cancer. Curr Opin Oncol. (2013) 25:637-45. doi: 10.1097/CCO.0000000000000006

84. Collison LW, Chaturvedi V, Henderson AL, Giacomin PR, Guy C, Bankoti J, et al. IL-35-mediated induction of a potent regulatory T cell population. Nat Immunol. (2010) 11:1093-101. doi: 10.1038/ni.1952

85. Chaturvedi V, Collison LW, Guy CS, Workman CJ, Vignali DAA. Cutting edge: human regulatory $\mathrm{T}$ cells require IL-35 to mediate suppression and infectious tolerance. J Immunol. (2011) 186:6661-6. doi: 10.4049/jimmunol.1100315

86. Patterson SJ, Pesenacker AM, Wang AY, Gillies J, Mojibian M, Morishita $\mathrm{K}$, et al. $\mathrm{T}$ regulatory cell chemokine production mediates pathogenic $\mathrm{T}$ cell attraction and suppression. J Clin Invest. (2016) 126:1039-51. doi: 10.1172/JCI83987

87. Thornton AM, Shevach EM. $\mathrm{CD} 4^{+} \mathrm{CD} 25^{+}$immunoregulatory $\mathrm{T}$ cells suppress polyclonal $\mathrm{T}$ cell activation in vitro by inhibiting interleukin 2 production. J Exp Med. (1998) 188:287-96.

88. Sojka DK, Hughson A, Sukiennicki TL, Fowell DJ. Early kinetic window of target $\mathrm{T}$ cell susceptibility to $\mathrm{CD} 25^{+}$regulatory $\mathrm{T}$ cell activity. J Immunol. (2005) 175:7274-80. doi: 10.4049/JIMMUNOL.175.11.7274

89. Pandiyan P, Zheng L, Ishihara S, Reed J, Lenardo MJ. CD $4^{+} \mathrm{CD} 25^{+}$Foxp $3^{+}$ regulatory $\mathrm{T}$ cells induce cytokine deprivation-mediated apoptosis of effector $\mathrm{CD}^{+}{ }^{+}$T cells. Nat Immunol. (2007) 8:1353-62. doi: 10.1038/ni1536

90. Thornton AM, Donovan EE, Piccirillo CA, Shevach EM. Cutting edge: IL-2 is critically required for the in vitro activation of $\mathrm{CD}^{+}{ }^{+} \mathrm{CD} 25^{+} \mathrm{T}$ cell suppressor function. J Immunol. (2004) 172:6519-23. doi: 10.4049/JIMMUNOL.172.11.6519

91. Chinen T, Kannan AK, Levine AG, Fan X, Klein U, Zheng Y, et al. An essential role for the IL-2 receptor in Treg cell function. Nat Immunol. (2016) 17:1322-33. doi: 10.1038/ni.3540

92. Montler R, Bell RB, Thalhofer C, Leidner R, Feng Z, Fox BA, et al. OX40, PD-1 and CTLA-4 are selectively expressed on tumor-infiltrating T cells in head and neck cancer. Clin Transl Immunol. (2016) 5:e70. doi: 10.1038/cti. 2016.16

93. Yates K, Bi K, Haining WN, Cantor H, Kim H-J. Comparative transcriptome analysis reveals distinct genetic modules associated with Helios expression in intratumoral regulatory T cells. Proc Natl Acad Sci USA. (2018) 115:2162-7. doi: $10.1073 /$ pnas. 1720447115

94. Jie H-B, Gildener-Leapman N, Li J, Srivastava RM, Gibson SP, Whiteside $\mathrm{TL}$, et al. Intratumoral regulatory $\mathrm{T}$ cells upregulate immunosuppressive molecules in head and neck cancer patients. Br J Cancer. (2013) 109:2629-35. doi: 10.1038/bjc.2013.645

95. Ghiringhelli F, Larmonier N, Schmitt E, Parcellier A, Cathelin D, Garrido $\mathrm{C}$, et al. $\mathrm{CD} 4{ }^{+} \mathrm{CD} 25^{+}$regulatory $\mathrm{T}$ cells suppress tumor immunity but are sensitive to cyclophosphamide which allows immunotherapy of established tumors to be curative. Eur J Immunol. (2004) 34:336-44. doi: 10.1002/eji.200324181

96. Wada S, Yoshimura K, Hipkiss EL, Harris TJ, Yen H-R, Goldberg MV, et al. Cyclophosphamide augments antitumor immunity: studies in an autochthonous prostate cancer model. Cancer Res. (2009) 69:4309-18. doi: 10.1158/0008-5472.CAN-08-4102

97. Ladoire S, Arnould L, Apetoh L, Coudert B, Martin F, Chauffert $\mathrm{B}$, et al. Pathologic complete response to neoadjuvant chemotherapy of breast carcinoma is associated with the disappearance of tumorinfiltrating Foxp3 ${ }^{+}$regulatory T cells. Clin Cancer Res. (2008) 14:2413-20. doi: 10.1158/1078-0432.CCR-07-4491

98. Scurr M, Pembroke T, Bloom A, Roberts D, Thomson A, Smart K, et al. Low-dose cyclophosphamide induces antitumor T-cell responses, which associate with survival in metastatic colorectal cancer. Clin Cancer Res. (2017) 23:6771-80. doi: 10.1158/1078-0432.CCR-17-0895

99. Sevko A, Sade-Feldman M, Kanterman J, Michels T, Falk CS, Umansky $\mathrm{L}$, et al. Cyclophosphamide promotes chronic inflammation-dependent 
immunosuppression and prevents antitumor response in melanoma. J Invest Dermatol. (2013) 133:1610-9. doi: 10.1038/JID.2012.444

100. Audia S, Nicolas A, Cathelin D, Larmonier N, Ferrand C, Foucher $\mathrm{P}$, et al. Increase of $\mathrm{CD}_{4}^{+} \mathrm{CD} 25^{+}$regulatory $\mathrm{T}$ cells in the peripheral blood of patients with metastatic carcinoma: a Phase I clinical trial using cyclophosphamide and immunotherapy to eliminate $\mathrm{CD}^{+}{ }^{+} \mathrm{CD} 25^{+}$T lymphocytes. Clin Exp Immunol. (2007) 150:523-30. doi: 10.1111/j.1365-2249.2007.03521.x

101. Hirschhorn-Cymerman D, Rizzuto GA, Merghoub T, Cohen AD, Avogadri F, Lesokhin AM, et al. OX40 engagement and chemotherapy combination provides potent antitumor immunity with concomitant regulatory $\mathrm{T}$ cell apoptosis. J Exp Med. (2009) 206:1103-16. doi: 10.1084/jem.20082205

102. Mkrtichyan M, Najjar YG, Raulfs EC, Abdalla MY, Samara R, RotemYehudar R, et al. Anti-PD-1 synergizes with cyclophosphamide to induce potent anti-tumor vaccine effects through novel mechanisms. Eur $J$ Immunol. (2011) 41:2977-86. doi: 10.1002/eji.201141639

103. Finke JH, Rini B, Ireland J, Rayman P, Richmond A, Golshayan A, et al. Sunitinib reversestype-1 immune suppression and decreases T-regulatory cells in renal cell carcinoma patients. Clin Cancer Res. (2008) 14:6674-82. doi: 10.1158/1078-0432.CCR-07-5212

104. Larmonier N, Janikashvili N, Lacasse CJ, Larmonier CB, Cantrell J, Situ E, et al. Imatinib mesylate inhibits $\mathrm{CD} 4^{+} \mathrm{CD} 25^{+}$regulatory $\mathrm{T}$ cell activity and enhances active immunotherapy against BCR-ABL negative tumors. $J$ Immunol. (2008) 181:6955-63. doi: 10.4049/jimmunol.181.10.6955

105. Desar IME, Jacobs JHFM, Hulsbergen-vandeKaa CA, Oyen WJG, Mulders PFA, van der Graaf WTA, et al. Sorafenib reduces the percentage of tumour infiltrating regulatory $\mathrm{T}$ cells in renal cell carcinoma patients. Int J Cancer. (2011) 129:507-12. doi: 10.1002/ijc.25674

106. Litzinger MT, Fernando R, Curiel TJ, Grosenbach DW, Schlom J, Palena C. IL-2 immunotoxin denileukin diftitox reduces regulatory T cells and enhances vaccine-mediated T-cell immunity. Blood. (2007) 110:3192-201. doi: 10.1182/blood-2007-06-094615

107. Rech AJ, Vonderheide RH. Clinical use of anti-CD25 antibody daclizumab to enhance immune responses to tumor antigen vaccination by targeting regulatory T cells. Ann N Y Acad Sci USA. (2009) 1174:99-106. doi: $10.1111 / j .1749-6632.2009 .04939 . x$

108. Onizuka S, Tawara I, Shimizu J, Sakaguchi S, Fujita T, Nakayama E. Tumor rejection by in vivo administration of anti-CD25 (interleukin-2 receptor alpha) monoclonal antibody. Cancer Res. (1999) 59:3128-33.

109. Betts G, Twohig J, Van den Broek M, Sierro S, Godkin A, Gallimore A. The impact of regulatory $\mathrm{T}$ cells on carcinogen-induced sarcogenesis. Br J Cancer. (2007) 96:1849-54. doi: 10.1038/sj.bjc.6603824

110. Dannull J, Su Z, Rizzieri D, Yang BK, Coleman D, Yancey D, et al. Enhancement of vaccine-mediated antitumor immunity in cancer patients after depletion of regulatory $\mathrm{T}$ cells. J Clin Invest. (2005) 115:3623-33. doi: 10.1172/JCI25947

111. Attia P, Maker AV, Haworth LR, Rogers-Freezer L, Rosenberg SA. Inability of a fusion protein of IL-2 and diphtheria toxin (Denileukin Diftitox, DAB389IL-2, ONTAK) to eliminate regulatory T lymphocytes in patients with melanoma. J Immunother. (2005) 28:582-92. doi: 10.1097/01.cji.0000175468.19742.10

112. Leong JW, Chase JM, Romee R, Schneider SE, Sullivan RP, Cooper MA, et al. Preactivation with IL-12, IL-15, and IL-18 induces CD25 and a functional high-affinity IL-2 receptor on human cytokine-induced memorylike natural killer cells. Biol Blood Marrow Transplant. (2014) 20:463-73. doi: 10.1016/J.BBMT.2014.01.006

113. Brisslert M, Bokarewa M, Larsson P, Wing K, Collins LV, Tarkowski A. Phenotypic and functional characterization of human $\mathrm{CD} 25^{+} \mathrm{B}$ cells. Immunology. (2006) 117:548-57. doi: 10.1111/j.1365-2567.2006.02331.x

114. Sato K, Sato N, Xu B, Nakamura Y, Nagaya T, Choyke PL, et al. Spatially selective depletion of tumor-associated regulatory $\mathrm{T}$ cells with near-infrared photoimmunotherapy. Sci Transl Med. (2016) 8:352ra110. doi: $10.1126 /$ scitranslmed.aaf6843

115. Liu W, Almo SC, Zang X. Co-stimulate or co-inhibit regulatory $\mathrm{T}$ cells, which side to go? Immunol Invest. (2016) 45:813-31. doi: 10.1080/08820139.2016.1186690

116. Mahne AE, Mauze S, Joyce-Shaikh B, Xia J, Bowman EP, Beebe AM, et al. Dual roles for regulatory T-cell depletion and costimulatory signaling in agonistic GITR targeting for tumor immunotherapy. Cancer Res. (2017) 77:1108-18. doi: 10.1158/0008-5472.CAN-16-0797

117. Simpson TR, Li F, Montalvo-Ortiz W, Sepulveda MA, Bergerhoff K, Arce F, et al. Fc-dependent depletion of tumor-infiltrating regulatory T cells codefines the efficacy of anti-CTLA-4 therapy against melanoma. J Exp Med. (2013) 210:1695-710. doi: 10.1084/jem.20130579

118. Selby MJ, Engelhardt JJ, Quigley M, Henning KA, Chen T, Srinivasan M, et al. Anti-CTLA-4 antibodies of IgG2a isotype enhance antitumor activity through reduction of intratumoral regulatory $\mathrm{T}$ cells. Cancer Immunol Res. (2013) 1:32-42. doi: 10.1158/2326-6066.CIR-13-0013

119. Bulliard Y, Jolicoeur R, Windman M, Rue SM, Ettenberg S, Knee DA, et al. Activating $\mathrm{Fc} \gamma$ receptors contribute to the antitumor activities of immunoregulatory receptor-targeting antibodies. J Exp Med. (2013) 210:1685-93. doi: 10.1084/jem.20130573

120. Du X, Tang F, Liu M, Su J, Zhang Y, Wu W, et al. A reappraisal of CTLA-4 checkpoint blockade in cancer immunotherapy. Cell Res. (2018) 28:416-32. doi: 10.1038/s41422-018-0011-0

121. Arce Vargas F, Furness AJS, Litchfield K, Joshi K, Rosenthal R, Ghorani E, et al. Fc effector function contributes to the activity of human anti-CTLA-4 antibodies. Cancer Cell. (2018) 33:649-63.e4. doi: 10.1016/j.ccell.2018.02.010

122. Liakou CI, Kamat A, Tang DN, Chen H, Sun J, Troncoso P, et al. CTLA4 blockade increases IFNgamma-producing $\mathrm{CD} 4^{+} \mathrm{ICOS}^{\text {hi }}$ cells to shift the ratio of effector to regulatory T cells in cancer patients. Proc Natl Acad Sci USA. (2008) 105:14987-92. doi: 10.1073/pnas.0806075105

123. Simeone E, Gentilcore G, Giannarelli D, Grimaldi AM, Caracò C, Curvietto $\mathrm{M}$, et al. Immunological and biological changes during ipilimumab treatment and their potential correlation with clinical response and survival in patients with advanced melanoma. Cancer Immunol Immunother. (2014) 63:675-83. doi: 10.1007/s00262-014-1545-8

124. Romano E, Kusio-Kobialka M, Foukas PG, Baumgaertner P, Meyer $\mathrm{C}$, Ballabeni $\mathrm{P}$, et al. Ipilimumab-dependent cell-mediated cytotoxicity of regulatory $\mathrm{T}$ cells ex vivo by nonclassical monocytes in melanoma patients. Proc Natl Acad Sci USA. (2015) 112:6140-5. doi: 10.1073/pnas. 1417320112

125. Sugiyama D, Nishikawa H, Maeda Y, Nishioka M, Tanemura A, Katayama I, et al. Anti-CCR4 mAb selectively depletes effector-type FoxP3 ${ }^{+} \mathrm{CD}^{+}$ regulatory $\mathrm{T}$ cells, evoking antitumor immune responses in humans. Proc Natl Acad Sci USA. (2013) 110:17945-50. doi: 10.1073/pnas.1316796110

126. Komatsu N, Mariotti-Ferrandiz ME, Wang Y, Malissen B, Waldmann H, Hori S. Heterogeneity of natural Foxp $3^{+} \mathrm{T}$ cells: a committed regulatory Tcell lineage and an uncommitted minor population retaining plasticity. Proc Natl Acad Sci USA. (2009) 106:1903-8. doi: 10.1073/pnas.0811556106

127. McClymont SA, Putnam AL, Lee MR, Esensten JH, Liu W, Hulme $\mathrm{MA}$, et al. Plasticity of human regulatory $\mathrm{T}$ cells in healthy subjects and patients with type 1 diabetes. I Immunol. (2011) 186:3918-26. doi: 10.4049/jimmunol.1003099

128. Dominguez-Villar M, Baecher-Allan CM, Hafler DA. Identification of $\mathrm{T}$ helper type 1-like, Foxp $3^{+}$regulatory T cells in human autoimmune disease. Nat Med. (2011) 17:673-5. doi: 10.1038/nm.2389

129. Hori S. Regulatory $\mathrm{T}$ cell plasticity: beyond the controversies. Trends Immunol. (2011) 32:295-300. doi: 10.1016/j.it.2011.04.004

130. Adeegbe DO, Nishikawa $\mathrm{H}$. Natural and induced T regulatory cells in cancer. Front Immunol. (2013) 4:190. doi: 10.3389/fimmu.2013.00190

131. Nakagawa H, Sido JM, Reyes EE, Kiers V, Cantor H, Kim H-J. Instability of Helios-deficient Tregs is associated with conversion to a T-effector phenotype and enhanced antitumor immunity. Proc Natl Acad Sci USA. (2016) 113:6248-53. doi: 10.1073/pnas.1604765113

132. Overacre-Delgoffe AE, Chikina M, Dadey RE, Yano H, Brunazzi EA, Shayan $\mathrm{G}$, et al. Interferon- $\gamma$ drives Treg fragility to promote anti-tumor immunity. Cell. (2017) 169:1130-41. doi: 10.1016/J.CELL.2017.05.005

133. Wang D, Quiros J, Mahuron K, Pai CC, Ranzani V, Young A, et al. Targeting EZH2 reprograms intratumoral regulatory $\mathrm{T}$ cells to enhance cancer immunity. Cell Rep. (2018) 23:3262-74. doi: 10.1016/j.celrep.2018.05.050

134. Liu Y, Wang L, Predina J, Han R, Beier UH, Wang L-CS, et al. Inhibition of p300 impairs Foxp $3^{+}$T regulatory cell function and promotes antitumor immunity. Nat Med. (2013) 19:1173-7. doi: 10.1038/nm.3286

135. Adeegbe DO, Liu Y, Lizotte PH, Kamihara Y, Aref AR, Almonte C, et al. Synergistic immunostimulatory effects and therapeutic benefit of combined 
histone deacetylase and bromodomain inhibition in non-small cell lung cancer. Cancer Discov. (2017) 7:852-67. doi: 10.1158/2159-8290.CD-16-1020

136. Stephens LA, Gray D, Anderton SM. $\mathrm{CD} 4^{+} \mathrm{CD} 25^{+}$regulatory T cells limit the risk of autoimmune disease arising from $\mathrm{T}$ cell receptor crossreactivity. Proc Natl Acad Sci USA. (2005) 102:17418-23. doi: 10.1073/pnas. 0507454102

137. Kim J, Lahl K, Hori S, Loddenkemper C, Chaudhry A, deRoos P, et al. Cutting edge: depletion of Foxp $3^{+}$cells leads to induction of autoimmunity by specific ablation of regulatory $\mathrm{T}$ cells in genetically targeted mice. J Immunol. (2009) 183:7631-4. doi: 10.4049/jimmunol.0804308

138. Mahnke K, Schonfeld K, Fondel S, Ring S, Karakhanova S, Wiedemeyer K, et al. Depletion of $\mathrm{CD} 4{ }^{+} \mathrm{CD} 25^{+}$human regulatory $\mathrm{T}$ cells in vivo: kinetics of Treg depletion and alterations in immune functions in vivo and in vitro. Int J Cancer. (2007) 120:2723-33. doi: 10.1002/ijc.22617

139. Berod L, Stüve P, Varela F, Behrends J, Swallow M, Kruse F, et al. Rapid rebound of the Treg compartment in DEREG mice limits the impact of Treg depletion on mycobacterial burden, but prevents autoimmunity. PLoS ONE. (2014) 9:e102804. doi: 10.1371/journal.pone.0102804

140. Wohlfert EA, Callahan MK, Clark RB. Resistance to $\mathrm{CD} 4{ }^{+} \mathrm{CD} 25^{+}$regulatory $\mathrm{T}$ cells and TGF-beta in Cbl-b ${ }^{-/-}$mice. J Immunol. (2004) 173:1059-65. doi: 10.4049/jimmunol.173.2.1059

141. Adams CO, Housley WJ, Bhowmick S, Cone RE, Rajan TV, Forouhar F, et al. $\mathrm{Cbl}^{-} \mathrm{b}^{-/-} \mathrm{T}$ cells demonstrate in vivo resistance to regulatory $\mathrm{T}$ cells but a context-dependent resistance to TGF-beta. J Immunol. (2010) 185:2051-8. doi: 10.4049/jimmunol.1001171

142. Paolino M, Penninger JM. Cbl-b in T-cell activation. Semin Immunopathol. (2010) 32:137-48. doi: 10.1007/s00281-010-0197-9

143. Fang D, Liu Y-C. Proteolysis-independent regulation of PI3K by Cblb-mediated ubiquitination in T cells. Nat Immunol. (2001) 2:870-5. doi: 10.1038/ni0901-870

144. Lin AE, Mak TW. The role of E3 ligases in autoimmunity and the regulation of autoreactive T cells. Curr Opin Immunol. (2007) 19:665-73. doi: 10.1016/J.COI.2007.10.002

145. Qiao G, Li Z, Molinero L, Alegre M-L, Ying H, Sun Z, et al. T-cell receptorinduced NF-B activation is negatively regulated by E3 ubiquitin ligase Cbl-b. Mol Cell Biol. (2008) 28:2470-80. doi: 10.1128/MCB.01505-07

146. Guo H, Qiao G, Ying H, Li Z, Zhao Y, Liang Y, et al. E3 ubiquitin ligase Cblb regulates Pten via Nedd4 in T cells independently of its ubiquitin ligase activity. Cell Rep. (2012) 1:472-82. doi: 10.1016/j.celrep.2012.04.008

147. Matalon O, Fried S, Ben-Shmuel A, Pauker MH, Joseph N, Keizer D, et al. Dephosphorylation of the adaptor LAT and phospholipase C- $\gamma$ by SHP-1 inhibits natural killer cell cytotoxicity. Sci Signal. (2016) 9:ra54. doi: 10.1126/scisignal.aad6182

148. Krawczyk C, Bachmaier K, Sasaki T, Jones RG, Snapper SB, Bouchard D, et al. $\mathrm{Cbl}-\mathrm{b}$ is a negative regulator of receptor clustering and raft aggregation in T cells. Immunity. (2000) 13:463-73. doi: 10.1016/S1074-7613(00)00046-7

149. Lutz-Nicoladoni C, Wolf D, Sopper S. Modulation of immune cell functions by the E3 ligase Cbl-b. Front Oncol. (2015) 5:58. doi: $10.3389 /$ fonc. 2015.00058

150. Wohlfert EA, Clark RB. 'Vive la Résistance!'-the PI3K-Akt pathway can determine target sensitivity to regulatory $\mathrm{T}$ cell suppression. Trends Immunol. (2007) 28:154-60. doi: 10.1016/j.it.2007.02.003

151. Mercadante ER, Lorenz UM. Breaking free of control: how conventional T cells overcome regulatory T cell suppression. Front Immunol. (2016) 7:193. doi: 10.3389/fimmu.2016.00193

152. Tran CW, Saibil SD, Le Bihan T, Hamilton SR, Lang KS, You H, et al. Glycogen synthase kinase- 3 modulates cbl-b and constrains T cell activation. J Immunol. (2017) 199:4056-65. doi: 10.4049/jimmunol.1600396

153. Li D, Gal I, Vermes C, Alegre M-L, Chong ASF, Chen L, et al. Cutting edge: Cbl-b: one of the key molecules tuning CD28- and CTLA-4-mediated T cell costimulation. J Immunol. (2004) 173:7135-9. doi: 10.4049/jimmunol.173.12.7135

154. Fujiwara M, Anstadt EJ, Clark RB. Cbl-b deficiency mediates resistance to programed death-ligand 1/programed death-1 regulation. Front Immunol. (2017) 8:42. doi: 10.3389/fimmu.2017.00042

155. Peer S, Baier G, Gruber T. Cblb-deficient $\mathrm{T}$ cells are less susceptible to PD-L1-mediated inhibition. Oncotarget. (2017) 8:41841-53, doi: 10.18632 /oncotarget. 18360
156. Xiao Y, Qiao G, Tang J, Tang R, Guo H, Warwar S, et al. Protein tyrosine phosphatase SHP-1 modulates $\mathrm{T}$ cell responses by controlling Cbl-b degradation. J Immunol. (2015) 195:4218-27. doi: 10.4049/jimmunol.1501200

157. Mercadante ER, Lorenz UM. T cells deficient in the tyrosine phosphatase SHP-1 resist suppression by regulatory T cells. J Immunol. (2017) 199:12937. doi: 10.4049/jimmunol.1602171

158. Gruber T, Hinterleitner R, Hermann-Kleiter N, Meisel M, Kleiter I, Wang CM, et al. Cbl-b mediates TGF $\beta$ sensitivity by downregulating inhibitory SMAD7 in primary T cells. J Mol Cell Biol. (2013) 5:358-68. doi: $10.1093 / \mathrm{jmcb} / \mathrm{mjt} 017$

159. Wohlfert EA, Gorelik L, Mittler R, Flavell RA, Clark RB. Cutting edge: deficiency in the E3 ubiquitin ligase Cbl-b results in a multifunctional defect in T cell TGF-beta sensitivity in vitro and in vivo. J Immunol. (2006) 176:1316-20. doi: 10.4049/jimmunol.176.3.1316

160. Chiang YJ, Kole HK, Brown K, Naramura M, Fukuhara S, Hu R-J, et al. Cbl-b regulates the CD28 dependence of T-cell activation. Nature. (2000) 403:216-20. doi: 10.1038/35003235

161. Loeser S, Loser K, Bijker MS, Rangachari M, van der Burg SH, Wada T, et al. Spontaneous tumor rejection by cbl-b-deficient $\mathrm{CD}^{+}{ }^{+} \mathrm{T}$ cells. J Exp Med. (2007) 204:879-91. doi: 10.1084/jem.20061699

162. Lyon MF, Peters J, Glenister PH, Ball S, Wright E. The scurfy mouse mutant has previously unrecognized hematological abnormalities and resembles Wiskott-Aldrich syndrome. Proc Natl Acad Sci USA. (1990) 87:2433-7.

163. Godfrey VL, Wilkinson JE, Russell LB. X-linked lymphoreticular disease in the scurfy (sf) mutant mouse. Am J Pathol. (1991) 138:1379-87.

164. Fontenot JD, Rasmussen JP, Williams LM, Dooley JL, Farr AG, Rudensky AY. Regulatory $\mathrm{T}$ cell lineage specification by the forkhead transcription factor Foxp3. Immunity. (2005) 22:329-41. doi: 10.1016/J.IMMUNI.2005.01.016

165. Gronski MA, Boulter JM, Moskophidis D, Nguyen LT, Holmberg K, Elford AR, et al. TCR affinity and negative regulation limit autoimmunity. Nat Med. (2004) 10:1234-9. doi: 10.1038/nm1114

166. Chiang JY, Jang IK, Hodes R, Gu H, Boon T, Houghton AN, et al. Ablation of Cbl-b provides protection against transplanted and spontaneous tumors. J Clin Invest. (2007) 117:1029-36. doi: 10.1172/JCI29472

167. Stromnes IM, Blattman JN, Tan X, Jeevanjee S, Gu H, Greenberg PD. Abrogating Cbl-b in effector $\mathrm{CD}^{+} \mathrm{T}$ cells improves the efficacy of adoptive therapy of leukemia in mice. J Clin Invest. (2010) 120:3722-34. doi: 10.1172/JCI41991

168. Paolino M, Thien CBF, Gruber T, Hinterleitner R, Baier G, Langdon WY, et al. Essential role of E3 ubiquitin ligase activity in Cbl-b-regulated T cell functions. J Immunol. (2011) 186:2138-47. doi: 10.4049/jimmunol.1003390

169. Pasare C, Medzhitov R. Toll pathway-dependent blockade of $\mathrm{CD} 4^{+} \mathrm{CD} 25^{+}$ $\mathrm{T}$ cell-mediated suppression by dendritic cells. Science. (2003) 299:1033-6. doi: $10.1126 /$ science.282.5396.2085

170. Caramalho I, Lopes-Carvalho T, Ostler D, Zelenay S, Haury M, Demengeot J. Regulatory $\mathrm{T}$ cells selectively express toll-like receptors and are activated by lipopolysaccharide. J Exp Med. (2003) 197:403-11. doi: 10.1084/JEM.20021633

171. Gelman AE, Zhang J, Choi Y, Turka LA. Toll-like receptor ligands directly promote activated $\mathrm{CD} 4^{+} \mathrm{T}$ cell survival. J Immunol. (2004) 172:6065-73. doi: 10.4049/JIMMUNOL.172.10.6065

172. Rahman AH, Taylor DK, Turka LA. The contribution of direct TLR signaling to $\mathrm{T}$ cell responses. Immunol Res. (2009) 45:25-36. doi: 10.1007/s12026-009-8113-x

173. Gelman AE, Larosa DF, Zhang J, Walsh PT, Choi Y, Oriol Sunyer J, et al. The adaptor molecule MyD88 activates PI-3 kinase signaling in $\mathrm{CD} 4^{+} \mathrm{T}$ cells and enables $\mathrm{CpG}$ oligodeoxynucleotide-mediated costimulation. Immunity. (2006) 25:783-93. doi: 10.1016/j.immuni.2006.08.023

174. LaRosa DF, Gelman AE, Rahman AH, Zhang J, Turka LA, Walsh PT. CpG DNA inhibits $\mathrm{CD} 4{ }^{+} \mathrm{CD} 25^{+}$Treg suppression through direct MyD88dependent costimulation of effector $\mathrm{CD}^{+} \mathrm{T}$ cells. Immunol Lett. (2007) 108:183-8. doi: 10.1016/j.imlet.2006.12.007

175. Kawasaki T, Kawai T. Toll-like receptor signaling pathways. Front Immunol. (2014) 5:461. doi: 10.3389/fimmu.2014.00461

176. King CG, Kobayashi T, Cejas PJ, Kim T, Yoon K, Kim GK, et al. TRAF6 is a $\mathrm{T}$ cell-intrinsic negative regulator required for the maintenance of immune homeostasis. Nat Med. (2006) 12:1088-92. doi: 10.1038/nm1449 
177. Liu H, Komai-Koma M, Xu D, Liew FY. Toll-like receptor 2 signaling modulates the functions of $\mathrm{CD} 4{ }^{+} \mathrm{CD} 25^{+}$regulatory T cells. Proc Natl Acad Sci USA. (2006) 103:7048-53. doi: 10.1073/pnas.0601554103

178. Peng G, Guo Z, Kiniwa Y, Voo KS, Peng W, Fu T, et al. Toll-like receptor 8-mediated reversal of $\mathrm{CD}^{+}$regulatory $\mathrm{T}$ cell function. Science. (2005) 309:1380-4. doi: 10.1126/science.1113401

179. Conroy H, Marshall NA, Mills KHG. TLR ligand suppression or enhancement of Treg cells? A double-edged sword in immunity to tumours. Oncogene. (2008) 27:168-80. doi: 10.1038/sj.onc.1210910

180. Gerriets VA, Kishton RJ, Johnson MO, Cohen S, Siska PJ, Nichols AG, et al. Foxp3 and Toll-like receptor signaling balance Treg cell anabolic metabolism for suppression. Nat Immunol. (2016) 17:1459-66. doi: 10.1038/ni.3577

181. Kaczanowska S, Joseph AM, Davila E. TLR agonists: our best frenemy in cancer immunotherapy. J Leukoc Biol. (2013) 93:847-63. doi: 10.1189/jlb.1012501

182. Song Y-C, Liu S-J. A TLR9 agonist enhances the anti-tumor immunity of peptide and lipopeptide vaccines via different mechanisms. Sci Rep. (2015) 5:12578. doi: $10.1038 /$ srep 12578

183. Ji H, Liao G, Faubion WA, Abadía-Molina AC, Cozzo C, Laroux FS, et al. Cutting edge: the natural ligand for glucocorticoid-induced TNF receptorrelated protein abrogates regulatory T cell suppression. J Immunol. (2004) 172:5823-7. doi: 10.4049/JIMMUNOL.172.10.5823

184. Stephens GL, McHugh RS, Whitters MJ, Young DA, Luxenberg D, Carreno BM, et al. Engagement of glucocorticoid-induced TNFR familyrelated receptor on effector $\mathrm{T}$ cells by its ligand mediates resistance to suppression by $\mathrm{CD}^{+} \mathrm{CD} 25^{+} \mathrm{T}$ cells. J Immunol. (2004) 173:5008-20. doi: 10.4049/jimmunol.173.8.5008

185. Takeda I, Ine S, Killeen N, Ndhlovu LC, Murata K, Satomi S, et al. Distinct roles for the OX40-OX40 ligand interaction in regulatory and nonregulatory T cells. J Immunol. (2004) 172:3580-9. doi: 10.4049/jimmunol.172.6.3580

186. Elpek KG, Yolcu ES, Franke DDH, Lacelle C, Schabowsky R-H, Shirwan H. Ex vivo expansion of $\mathrm{CD} 4^{+} \mathrm{CD} 25^{+}$FoxP $3^{+} \mathrm{T}$ regulatory cells based on synergy between IL-2 and 4-1BB signaling. J Immunol. (2007) 179:7295-304. doi: 10.4049/jimmunol.179.11.7295

187. Robertson SJ, Messer RJ, Carmody AB, Mittler RS, Burlak C, Hasenkrug KJ. CD137 costimulation of CD8 ${ }^{+} \mathrm{T}$ cells confers resistance to suppression by virus-induced regulatory $\mathrm{T}$ cells. J Immunol. (2008) 180:5267-74. doi: 10.4049/jimmunol.180.8.5267

188. Voo KS, Bover L, Harline ML, Vien LT, Facchinetti V, Arima K, et al. Antibodies targeting human OX40 expand effector $\mathrm{T}$ cells and block inducible and natural regulatory $\mathrm{T}$ cell function. J Immunol. (2013) 191:3641-50. doi: 10.4049/jimmunol.1202752

189. Nishikawa H, Kato T, Hirayama M, Orito Y, Sato E, Harada N, et al. Regulatory T cell-resistant CD8 ${ }^{+} \mathrm{T}$ cells induced by glucocorticoid-induced tumor necrosis factor receptor signaling. Cancer Res. (2008) 68:5948-54. doi: 10.1158/0008-5472.CAN-07-5839

190. Ko K, Yamazaki S, Nakamura K, Nishioka T, Hirota K, Yamaguchi T, et al. Treatment of advanced tumors with agonistic anti-GITR $\mathrm{mAb}$ and its effects on tumor-infiltrating Foxp $3{ }^{+} \mathrm{CD} 25^{+} \mathrm{CD} 4^{+}$regulatory T cells. J Exp Med. (2005) 202:885-91. doi: 10.1084/jem.20050940

191. Shimizu J, Yamazaki S, Takahashi T, Ishida Y, Sakaguchi S. Stimulation of $\mathrm{CD}_{2} 5^{+} \mathrm{CD} 4{ }^{+}$regulatory $\mathrm{T}$ cells through GITR breaks immunological self-tolerance. Nat Immunol. (2002) 3:135-42. doi: 10.1038/ni759

192. Schaer DA, Budhu S, Liu C, Bryson C, Malandro N, Cohen A, et al. GITR pathway activation abrogates tumor immune suppression through loss of regulatory T cell lineage stability. Cancer Immunol Res. (2013) 1:320-31. doi: 10.1158/2326-6066.CIR-13-0086

193. Ephrem A, Epstein AL, Stephens GL, Thornton AM, Glass D, Shevach EM. Modulation of Treg cells/T effector function by GITR signaling is contextdependent. Eur J Immunol. (2013) 43:2421-9. doi: 10.1002/eji.201343451

194. Ramirez-Montagut T, Chow A, Hirschhorn-Cymerman D, Terwey TH, Kochman AA, Lu S, et al. Glucocorticoid-induced TNF receptor family related gene activation overcomes tolerance/ignorance to melanoma differentiation antigens and enhances antitumor immunity. J Immunol. (2006) 176:6434-42. doi: 10.4049/jimmunol.176.11.6434

195. Wan S, Xia C, Morel L. IL-6 produced by dendritic cells from lupus-prone mice inhibits $\mathrm{CD} 4^{+} \mathrm{CD} 25^{+} \mathrm{T}$ cell regulatory functions. J Immunol. (2007) 178:271-9. doi: 10.4049/jimmunol.178.1.271
196. Peluso I, Fantini MC, Fina D, Caruso R, Boirivant M, MacDonald TT, et al. IL-21 counteracts the regulatory $\mathrm{T}$ cell-mediated suppression of human $\mathrm{CD}^{+} \mathrm{T}$ lymphocytes. J Immunol. (2007) 178:732-9. doi: 10.4049/JIMMUNOL.178.2.732

197. Ben Ahmed M, Belhadj Hmida N, Moes N, Buyse S, Abdeladhim M, Louzir $\mathrm{H}$, et al. IL-15 renders conventional lymphocytes resistant to suppressive functions of regulatory $\mathrm{T}$ cells through activation of the phosphatidylinositol 3-kinase pathway. J Immunol. (2009) 182:6763-70. doi: 10.4049/jimmunol.0801792

198. Ruprecht CR, Gattorno M, Ferlito F, Gregorio A, Martini A, Lanzavecchia A, et al. Coexpression of $\mathrm{CD} 25$ and $\mathrm{CD} 27$ identifies FoxP3 ${ }^{+}$regulatory $\mathrm{T}$ cells in inflamed synovia. J Exp Med. (2005) 201:1793-803. doi: 10.1084/jem.20050085

199. Takahashi T, Kuniyasu Y, Toda M, Sakaguchi N, Itoh $M$, Iwata $M$, et al. Immunologic self-tolerance maintained by $\mathrm{CD} 25^{+} \mathrm{CD} 4^{+}$naturally anergic and suppressive $\mathrm{T}$ cells: induction of autoimmune disease by breaking their anergic/suppressive state. Int Immunol. (1998) 10:1969-80. doi: 10.1093/intimm/10.12.1969

200. Sims JE, Smith DE. The IL-1 family: regulators of immunity. Nat Rev Immunol. (2010) 10:89-102. doi: 10.1038/nri2691

201. O'Shea JJ, Plenge R. JAK and STAT signaling molecules in immunoregulation and immune-mediated disease. Immunity. (2012) 36:542-50. doi: 10.1016/J.IMMUNI.2012.03.014

202. Rochman Y, Spolski R, Leonard WJ. New insights into the regulation of T cells by $\gamma$ c family cytokines. Nat Rev Immunol. (2009) 9:480-90. doi: $10.1038 /$ nri2580

203. O’Sullivan BJ, Thomas HE, Pai S, Santamaria P, Iwakura Y, Steptoe RJ, et al. IL-1 beta breaks tolerance through expansion of $\mathrm{CD} 25^{+}$effector $\mathrm{T}$ cells. $J$ Immunol. (2006) 176:7278-87. doi: 10.4049/JIMMUNOL.176.12.7278

204. Pace L, Rizzo S, Palombi C, Brombacher F, Doria G. Cutting edge: IL-4-induced protection of $\mathrm{CD} 4{ }^{+} \mathrm{CD} 25^{-}$Th cells from $\mathrm{CD} 4{ }^{+} \mathrm{CD} 25^{+}$ regulatory $\mathrm{T}$ cell-mediated suppression. J Immunol. (2006) 176:3900-4. doi: 10.4049/JIMMUNOL.176.7.3900

205. van Amelsfort JMR, van Roon JAG, Noordegraaf M, Jacobs KMG, Bijlsma JWJ, Lafeber FPJG, et al. Proinflammatory mediator-induced reversal of $\mathrm{CD}^{+}{ }^{+}, \mathrm{CD} 25^{+}$regulatory $\mathrm{T}$ cell-mediated suppression in rheumatoid arthritis. Arthritis Rheum. (2007) 56:732-42. doi: 10.1002/art.22414

206. Pellegrini M, Calzascia T, Elford AR, Shahinian A, Lin AE, Dissanayake $\mathrm{D}$, et al. Adjuvant IL-7 antagonizes multiple cellular and molecular inhibitory networks to enhance immunotherapies. Nat Med. (2009) 15:1953. doi: $10.1038 / \mathrm{nm} .1953$

207. Klebanoff CA, Finkelstein SE, Surman DR, Lichtman MK, Gattinoni L, Theoret MR, et al. IL-15 enhances the in vivo antitumor activity of tumorreactive CD8 ${ }^{+}$T cells. Proc Natl Acad Sci USA. (2004) 101:1969-74. doi: 10.1073/pnas.0307298101

208. Overwijk WW, Theoret MR, Finkelstein SE, Surman DR, de Jong LA, VythDreese FA, et al. Tumor regression and autoimmunity after reversal of a functionally tolerant state of self-reactive CD8 ${ }^{+}$T cells. J Exp Med. (2003) 198:569-80. doi: 10.1084/jem.20030590

209. Sakaguchi S, Vignali DAA, Rudensky AY, Niec RE, Waldmann H. The plasticity and stability of regulatory T cells. Nat Rev Immunol. (2013) 13:4617. doi: 10.1038/nri3464

210. Sawant DV, Vignali DAA. Once a Treg, always a Treg? Immunol Rev. (2014) 259:173-91. doi: 10.1111/imr.12173

211. Noval Rivas M, Burton OT, Wise P, Charbonnier L-M, Georgiev P, Oettgen $\mathrm{HC}$, et al. Regulatory $\mathrm{T}$ cell reprogramming toward a Th2-cell-like lineage impairs oral tolerance and promotes food allergy. Immunity. (2015) 42:51223. doi: 10.1016/J.IMMUNI.2015.02.004

212. Shrestha S, Yang K, Guy C, Vogel P, Neale G, Chi H. Treg cells require the phosphatase PTEN to restrain TH1 and TFH cell responses. Nat Immunol. (2015) 16:178-87. doi: 10.1038/ni.3076

213. Huynh A, DuPage M, Priyadharshini B, Sage PT, Quiros J, Borges CM, et al. The phosphatase PTEN-mediated control of PI-3 kinase in Tregs cells maintains homeostasis and lineage stability. Nat Immunol. (2015) 16:188-96. doi: 10.1038/ni.3077

214. Schmitz I, Schneider C, Fröhlich A, Frebel H, Christ D, Leonard WJ, et al. IL-21 restricts virus-driven Treg cell expansion in chronic LCMV infection. PLoS Pathog. (2013) 9:e1003362. doi: 10.1371/journal.ppat.1003362 
215. Attridge K, Wang CJ, Wardzinski L, Kenefeck R, Chamberlain JL, Manzotti C, et al. IL-21 inhibits T cell IL-2 production and impairs Treg homeostasis. Blood. (2012) 119:4656-64. doi: 10.1182/blood-2011-1 0-388546

216. Tanaka A, Sakaguchi S. Regulatory T cells in cancer immunotherapy. Cell Res. (2017) 27:109-18. doi: 10.1038/cr.2016.151

217. Kurose K, Ohue $\mathrm{Y}$, Wada H, Iida S, Ishida T, Kojima T, et al. Phase Ia study of FoxP3 ${ }^{+} \mathrm{CD} 4$ Treg depletion by infusion of a humanized anti-CCR4 antibody, KW-0761, in cancer patients. Clin Cancer Res. (2015) 21:4327-36. doi: 10.1158/1078-0432.CCR-15-0357

218. Dudley ME, Yang JC, Sherry R, Hughes MS, Royal R, Kammula U, et al. Adoptive cell therapy for patients with metastatic melanoma: evaluation of intensive myeloablative chemoradiation preparative regimens. J Clin Oncol. (2008) 26:5233-9. doi: 10.1200/JCO.2008. 16.5449

219. Radvanyi LG, Bernatchez C, Zhang M, Fox PS, Miller P, Chacon J, et al. Specific lymphocyte subsets predict response to adoptive cell therapy using expanded autologous tumor-infiltrating lymphocytes in metastatic melanoma patients. Clin Cancer Res. (2012) 18:6758-70. doi: 10.1158/1078-0432.CCR-12-1177

220. Rosenberg SA, Yang JC, Sherry RM, Kammula US, Hughes MS, Phan GQ, et al. Durable complete responses in heavily pretreated patients with metastatic melanoma using T-cell transfer immunotherapy. Clin Cancer Res. (2011) 17:4550-7. doi: 10.1158/1078-0432.CCR-1 1-0116

221. Pilon-Thomas S, Kuhn L, Ellwanger S, Janssen W, Royster E, Marzban S, et al. Efficacy of adoptive cell transfer of tumor-infiltrating lymphocytes after lymphopenia induction for metastatic melanoma. J Immunother. (2012) 35:615-20. doi: 10.1097/CJI.0b013e31826e8f5f
222. Klatzmann D, Abbas AK. The promise of low-dose interleukin-2 therapy for autoimmune and inflammatory diseases. Nat Rev Immunol. (2015) 15:28394. doi: $10.1038 /$ nri3823

223. Hirakawa M, Matos TR, Liu H, Koreth J, Kim HT, Paul NE, et al. Low-dose IL-2 selectively activates subsets of $\mathrm{CD} 4^{+}$Tregs and NK cells. JCI Insight. (2016) 1:e89278. doi: 10.1172/jci.insight.89278

224. Charych DH, Hoch U, Langowski JL, Lee SR, Addepalli MK, Kirk PB, et al. NKTR-214, an engineered cytokine with biased IL2 receptor binding, increased tumor exposure, and marked efficacy in mouse tumor models. Clin Cancer Res. (2016) 22:680-90. doi: 10.1158/1078-0432.CCR-15-1631

225. Levin AM, Bates DL, Ring AM, Krieg C, Lin JT, Su L, et al. Exploiting a natural conformational switch to engineer an interleukin-2 "superkine". Nature. (2012) 484:529-33. doi: 10.1038/nature10975

226. Arenas-Ramirez N, Zou C, Popp S, Zingg D, Brannetti B, Wirth E, et al. Improved cancer immunotherapy by a $\mathrm{CD} 25^{-}$mimobody conferring selectivity to human interleukin-2. Sci Transl Med. (2016) 8:367ra166. doi: $10.1126 /$ scitranslmed.aag3187

Conflict of Interest Statement: The authors declare that the research was conducted in the absence of any commercial or financial relationships that could be construed as a potential conflict of interest.

Copyright (c) 2019 Han, Toker, Liu and Ohashi. This is an open-access article distributed under the terms of the Creative Commons Attribution License (CC BY). The use, distribution or reproduction in other forums is permitted, provided the original author(s) and the copyright owner(s) are credited and that the original publication in this journal is cited, in accordance with accepted academic practice. No use, distribution or reproduction is permitted which does not comply with these terms. 